\title{
Does stricter immigration policy affect college enrollment and public-private school choice of natives?
}

\section{Christian Gunadi}

Correspondence:

christian.gunadi@email.ucr.edu Department of Economics,

University of California, Riverside, 900 University Ave,92521 Riverside, CA, USA

\begin{abstract}
In recent decades, the USA has admitted a large number of foreign-born students into its educational system, raising concerns that the presence of foreign-born students would adversely impact the educational achievement of US-born students and incentivize them to move to private schools where there are fewer immigrant students. In this article, I attempt to extend our understanding of how stricter immigration policy, such as the Legal Arizona Workers Act (LAWA), may affect college enrollment and the public-private school choice of US-born individuals. The analysis shows that the share of immigrant students across Arizona's educational system declined significantly by the passage of LAWA: the share of foreign-born students in elementary and secondary schools in Arizona would be higher by approximately 1.1 and 1.7 percentage points, respectively, in the absence of LAWA. Similarly, the share of foreign-born college students in Arizona declined significantly by 1.5 percentage points due to LAWA. Despite this decline, there is no evidence that LAWA has statistically significantly affected natives' college enrollment rates. However, there is evidence that LAWA reduces the proportion of US-born white non-Hispanic student in higher education attending private colleges.
\end{abstract}

JEL Classification: J24, J61, 120

Keywords: Immigration, Native college enrollment, Public school, Education

\section{Introduction}

Between 1990 and 2010, the number of foreign students in US higher education had almost doubled, increasing the share from 2.9 to $3.5 \%$ of all college students (IIE 2017). Over the same time period, the share of foreign-born students in public schools increased by approximately $10 \%$ from 5.23 to $5.76 \%$ (Murray 2016). In the face of these trends, there are concerns that the influx of foreign-born students may adversely impact the educational outcomes of US-born students as well as inducing them to move to private schools where there are fewer immigrant students. Prior studies have reported that foreign-born students "crowd out" natives from colleges and graduate programs (Hoxby 1998; Borjas 2004), while the presence of students with limited English proficiency presents a barrier to other students' learning in US schools (Chin et al. 2013; Diette and Uwaifo Oyelere 2014).

(C) The Author(s). 2018 Open Access This article is distributed under the terms of the Creative Commons Attribution 4.0 International License (http://creativecommons.org/licenses/by/4.0/), which permits unrestricted use, distribution, and reproduction in any medium, provided you give appropriate credit to the original author(s) and the source, provide a link to the Creative Commons license, and indicate if changes were made. 
In this paper, I attempt to extend our understanding of how stricter immigration policy such as the Legal Arizona Workers Act (LAWA) may affect college enrollment and public-private school choice of natives. I begin my analysis by examining how LAWA affected the size of foreign-born student population in Arizona. After the adoption of LAWA in 2007, all employers in Arizona are required to verify if a worker is authorized to work in the USA through the federal E-Verify system. Although foreign-born students are not directly targeted by the legislation, there are a few reasons why LAWA could reduce the population of foreignborn students in Arizona. First, some immigrant students have household members (e.g., parents, siblings, spouses) who are undocumented. These students may leave Arizona as a result of LAWA's impact on a household member. Second, as the adoption of LAWA may signal an anti-immigrant sentiment in the state, foreign-born students may decide to pursue their education in other states where such sentiment is not as prevalent. Indeed, I find that the share of immigrant students across Arizona's educational system declined significantly by the passage of LAWA. In the absence of LAWA, the share of foreign-born students in elementary and secondary schools in Arizona would be higher by approximately 1.1 and 1.7 percentage points, respectively. Similarly, the share of foreign-born college students in Arizona would be higher by 1.5 percentage points in the absence of LAWA. These results suggest that LAWA can serve as a natural experiment to examine how a stricter immigration policy could affect college enrollment rates and public-private school choices of natives.

After establishing that LAWA has reduced the size of foreign-born student population in Arizona, I proceed to examine whether the implementation of LAWA has affected natives' enrollment rates in higher education. Unfortunately, theory does not provide a clear prediction on how LAWA would impact the college enrollment rate of natives. As noted above, an influx of foreign-born students may crowd natives out from higher education because academic resources/number of admission slots in universities are relatively fixed in the short run (Hoxby 1998; Borjas 2004). At the same time, low-skilled immigration may induce more natives to pursue higher education by allowing them to avoid direct competition with immigrants in the low-skilled labor market (Jackson 2015; Hunt 2017). Therefore, LAWA is expected to have two competing effects influencing natives' college enrollment rates. The decline of foreign-born student population in colleges may increase the enrollment rate of natives by increasing academic resources/number of admission slots available to them, while less competition with immigrants in the lowskilled labor market would incentivize natives to enter the labor market instead of pursuing higher education. The analysis shows that there is no evidence that LAWA has statistically significantly affected natives' college enrollment rates in Arizona. Moreover, there is no evidence that LAWA has improved college enrollment rate of black and Hispanic natives, who have been argued to compete for similar academic resources (e.g., grants for needy students) as foreign-born students (Hoxby 1998).

To further investigate how LAWA may affect the educational choice of natives, I examine whether the adoption of LAWA affected the share of US-born students enrolled in private school in Arizona. The tendency of native students to move to private 
schools in response to the influx of foreign-born students was first documented by Betts and Fairlie (2003), noting "native flight" may reduce the quality and support for public education. Since then, similar evidence was found in Denmark (Gerdes 2013) and in Italy (Farre et al. 2018). Although a positive relationship between immigration and USborn students' tendency to move into private schools has been found in the literature, the mechanism driving this native flight is not entirely clear; however, there are a few potential explanations. Recent works have documented that an influx of foreign-born students with limited English proficiency adversely affects native students' performance in math and reading test scores (Chin et al. 2013; Diette and Uwaifo Oyelere 2014). Due to this potential effect, native households may respond to the inflow of foreign-born students by enrolling their children in private school. Similarly, the presence of foreign-born students with limited English proficiency may require public schools to allocate more resources toward them, leaving fewer resources for native students. In response to this, native families may move their children to private schools. Considering that LAWA reduces the share of foreign-born students enrolled in public school, the adoption of LAWA can be expected to lower the share of US-born students enrolled in private schools in Arizona as native households may choose not to send their children to private schools as a result of LAWA implementation. The analysis shows that the proportion of US-born white non-Hispanic student in higher education attending private colleges in Arizona declines by approximately 2.7 percentage points. As there are approximately $19 \%$ of US-born white non-Hispanic student in college attending private school before LAWA, this decline corresponds to $14 \%$ decrease relative to its pre-LAWA average.

These results suggest that a stricter immigration policy aimed at improving natives' college enrollment rates may not necessarily achieve its objective. In Arizona, the adoption of LAWA did result in the decline of immigrant students across its educational system; however, there is no evidence that this decline improves college enrollment rates among natives. It is worth noting that LAWA did reduce the proportion of US-born white nonHispanic college student attending private schools, in line with previous studies who find evidence of native flight to private schools in response to an influx of immigrant students (Betts and Fairlie 2003; Gerdes 2013; Farre et al. 2018).

The findings in this study contribute to the new emerging literature that examines how educational outcomes of students are affected by immigration policies. A few studies on this topic have focused on the impact of the policy on the immigrant students themselves. For example, a study by Cattaneo MA and Wolter SC (2015) found that a policy change in Switzerland that allows free movement of labor for citizens of the European Economic Area (EEA) increased the Program for International Student Assessment (PISA) scores of immigrant students, and most of the improvement can be attributed to the changes in the background characteristics of their parents. More recently, the work by Amuedo-Dorantes and Lopez (2017) found that a higher intensity of interior immigration enforcement in the USA increases the probability of Hispanic youth with likely unauthorized parents repeating grades and dropping out of school. I contribute to this literature by focusing on the educational outcomes of native students; in particular, I examine whether natives' college enrollment rates and public-private school choice are affected by a stricter immigration policy such as LAWA. 
This paper is constructed as follows. Section 2 describes the background of LAWA. Section 3 describes the methodology used for the analyses. Section 4 documents the main findings, and Section 5 concludes.

\section{Background}

The passage of Immigration Reform and Control Act (IRCA) in 1986 requires new hires to present documents verifying their eligibility to work legally in the USA and imposes sanctions on employers knowingly hiring undocumented immigrants. This measure to prevent unauthorized employment in IRCA, however, has been argued to be ineffective because there was no reliable, quick way to verify the information presented as part of the hiring process (Cooper and O'Neil 2005). The E-Verify system was designed to address this shortcoming. It was rolled out to several states in 1997 under the name of Basic Pilot. Participating employer enters the new hire information from the employment eligibility form (Form I-9), and the E-Verify system checks the information with the Social Security Administration (SSA) and Department of Homeland Security (DHS). If there is a discrepancy, the employer is notified of a tentative nonconfirmation, and the new worker has eight federal working days to contest the discrepancy. While the discrepancy is being contested, the employer cannot fire the new hire. After that period, however, the employer must fire the new employee if the discrepancy is not resolved. For authorized workers, the inaccuracy rate of E-Verify is approximately $1 \%$, while for unauthorized workers, the error rate is approximately $54 \%$ (Westat 2009).

LAWA was signed into law in July 2007 and implemented on January 1, 2008. It is the first law of its kind requiring all businesses in a state to verify the employment authorization of new hires through the federal E-Verify system. The penalty for knowingly hiring an undocumented immigrant is considerably harsh; a business license can be revoked after a second violation under LAWA. Since its adoption, LAWA has had a dramatic effect on the use of E-Verify in Arizona. In March 2007, only 277 employers used the E-Verify system (Westat 2009). By mid-2008, 6 months after the implementation of LAWA, the number of employers using the federal E-Verify system increased by approximately 50 times to 14,116 employers (Westat 2009). During the same time period, the use of E-Verify system in all other states increased by only threefold (Westat 2009).

Previous studies have examined how LAWA has affected the relative size of likely unauthorized population in Arizona (Bohn et al. 2014) as well as the wage and employment outcomes of low-skilled native men in Arizona (Bohn et al. 2015). In my previous work (Gunadi, C: Examining the impact of Legal Arizona Worker Act on native female labor supply in the United States, unpublished), I examine the impact of LAWA on native female labor supply in the USA. In this paper, building on my previous work, I exploit the adoption of LAWA in Arizona to examine the effect of a sudden change in the number of immigrants on college enrollment rates and public-private school choice of natives.

\section{Empirical methodology}

To analyze the impact of LAWA, I use the synthetic control method (SCM) developed by Abadie et al. (2010; 2015). Intuitively, the method derives a weight that combines states to create a new synthetic Arizona that best resembles the pre-LAWA Arizona's 
characteristics and trends. The use of SCM in comparative case studies has an advantage of reducing the arbitrary nature of choosing a "proper" control state by the researcher that is not always well justified. Furthermore, the pretreatment characteristics of the treated state can often be much more accurately approximated by a combination of untreated states than by any single one (Abadie et al. 2010; 2015). Formally, consider $J+1$ states indexed by $j=0,1, \ldots, J$. Let the value $j=0$ correspond to Arizona, while the rest of the states $(j=1, \ldots, J)$ are candidate contributors to the control group (i.e., the donor pool). Let $G_{0}$ be a $(k \times 1)$ vector whose elements are equal to the values of the pretreatment characteristics of Arizona that we want to match. Similarly, let $G_{1}$ be a $(k \times J)$ matrix collecting the values of the same variables in the donor pool.

The synthetic control method identifies the vector of weights $W^{*}=\left(w_{1}, \ldots, w_{j}\right)^{\prime}$ that minimize the difference between $G_{0}$ and $G_{1} W$ :

$$
W^{*}=\operatorname{argmin}\left(G_{0}-G_{1} W\right)^{\prime} V\left(G_{0}-G_{1} W\right) \quad \text { subject to } \quad \sum_{j=1}^{J} w_{j}=1, w_{j} \geq 0
$$

where $V$ is a $(k \times k)$ diagonal, positive-definite matrix that assigns weights according to the relative importance of the pretreatment characteristics in the objective function. ${ }^{1}$ After the optimal weighting vector $W^{*}$ is identified, both the pre- and post-treatment values of the outcome variable for synthetic Arizona can be calculated by weighting each state appropriately. The post-treatment values of synthetic Arizona then serve as the counterfactual outcomes for Arizona.

Once synthetic Arizona has been constructed, I follow the usual difference-indifferences framework to estimate the impact of LAWA:

$$
\mathrm{DD}=\left(\text { Outcome }_{\mathrm{post}}^{\mathrm{AZ}}-\text { Outcome }_{\mathrm{pre}}^{\mathrm{AZ}}\right)-\left(\text { Outcome }_{\text {post }}^{\text {synth }}-\text { Outcome }_{\mathrm{pre}}^{\text {synth }}\right)
$$

where Outcome $\mathrm{A}_{\text {post }}^{\mathrm{AZ}}$ is the average value of the outcome of interest for Arizona in the posttreatment period 2007 through 2015, and Outcome $\mathrm{pre}_{\mathrm{AZ}}^{\mathrm{AZ}}$ is the corresponding average for the pretreatment period 2000 through 2006. Similarly, Outcome post $_{\text {synth }}^{\text {and Outcome }}$ pre are the corresponding averages for synthetic Arizona. I exclude from the donor pool six states (i.e., Alabama, Georgia, Mississippi, North Carolina, South Carolina, and Utah) that implemented similar universal E-Verify programs after 2007 to prevent possible bias in the estimate of the impact of LAWA. I use the 5\% 2000 Census and American Community Survey (ACS) 2001-2015 available from IPUMS (Ruggles et al. 2015) for all analyses in this study.

A possible threat to the empirical strategy proposed above is that the Great Recession closely coincided with the adoption of LAWA in Arizona, which may bias the impact of LAWA. It should be noted that the synthetic control method approach already takes into account any changes that affect the country as a whole, and unless the Great Recession affects the Arizona labor markets differently than the rest of the country, it will not threaten the validity of my findings. A concern is that one of the industries that were hit hardest by the Great Recession, construction, is a leading employer of lowskilled workers in Arizona. If the recession had a larger impact on Arizona's labor market 
compared to the rest of the US states, then the impact of LAWA on natives' college enrollment rates would be overestimated as more US-born students in Arizona may choose to enroll in college rather than entering the labor market relative to other states. However, recent studies by Bohn et al. (2014); Bohn et al. (2015) show that the decline in the annual growth of employment in the construction industry in Arizona is similar to the neighboring states during the Great Recession, providing support to the empirical strategy proposed. Nonetheless, I include the share of the construction industry for the pretreatment characteristics to be matched, which should mitigate the possible bias that might arise. Additionally, to further address the potential differential impact that the Great Recession might have had on Arizona relative to the rest of the country, I include the share of agricultural and manufacturing industries, the unemployment rate, the share of foreign-born in the state, the share of non-Hispanic whites in the population, the average age in the state, and the outcome variable itself from 2001 to 2006 as pretreatment characteristics to be minimized between Arizona and its synthetic control $^{2}$.

Another threat to the identification strategy proposed above is that a controversial Arizona state bill, S.B. 1070, which gave local law enforcement agencies more power in enforcing immigration laws, passed in 2010 and may also bias the impact of LAWA. However, before the law was supposed to take effect, a federal judge issued a preliminary injunction that blocked its most controversial provisions, and by 2012, the Supreme Court had struck down many of these provisions. It is worth noting that a recent study by Amuedo-Dorantes and Lozano (2015) found that S.B. 1070 had a "minimal to null" impact on the share of non-citizen Hispanics in Arizona. It is unlikely, therefore, that the passage of S.B. 1070 had much impact on reducing the share of foreign-born students in Arizona.

Finally, there is a concern that the decline in the size of foreign-born student population in college might be caused by the "Public Program Eligibility Act" (PPEA) instead of LAWA. PPEA became effective on December 7, 2006, in Arizona, and requires verification of immigration status of college students applying for any financial assistance (including reduced in-state tuition) paid by the state funds. ${ }^{3}$ Considering that the act was effective at the very end of 2006, any impact of PPEA, if there is any, should have been observed in 2007. ${ }^{4}$ However, as I will show later, the decline in the foreign-born share of college enrollment in Arizona relative to its synthetic control occurs in the year of LAWA implementation (2008) instead of 2007. Considering that the timing of the decline in the number of college foreign-born students does not match to the year in which PPEA should have taken effect, it is quite unlikely that the decline is caused by PPEA.

\section{Results}

\subsection{LAWA and the size of the foreign-born student population in Arizona}

In this subsection, I present evidence that LAWA led to a decline in the size of the foreign-born student population in Arizona. Figure 1a shows that the number of immigrant students in elementary schools in Arizona falls dramatically relative to its synthetic control after 2007. ${ }^{5}$ The difference-in-difference estimate shows that there would be 9091 more foreign-born elementary school students in Arizona in the absence of LAWA (panel A of Table 1). Since there are approximately 26,000 foreign-born elementary 


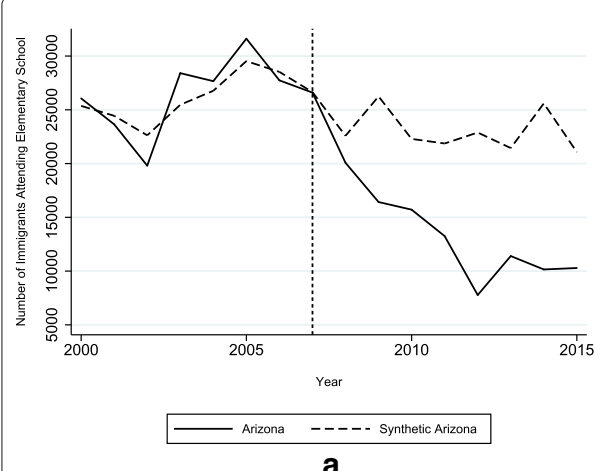

a

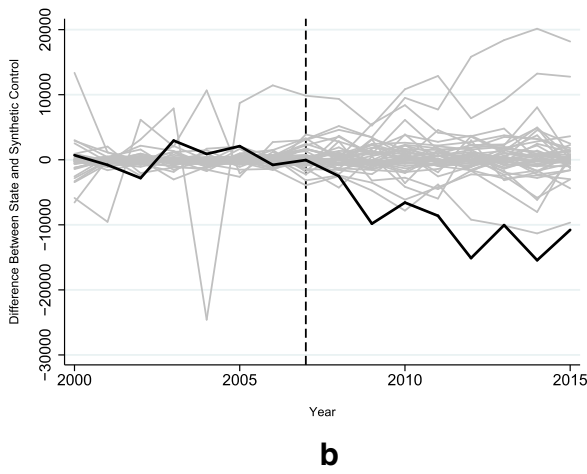

b

Fig. 1 LAWA and number of immigrants in elementary school. a Number of immigrants. b Permutation test

school students in Arizona before 2007, this decline represents a reduction of 35\% of foreign-born elementary school students in pre-LAWA Arizona.

To test whether this decline is statistically significant, I conduct a permutation test as suggested by Abadie et al. (2010) and Abadie et al. (2015). To do this, I first apply the synthetic control method to every state included in the donor pool to

Table 1 LAWA and size of foreign-born population in Arizona's education system

\begin{tabular}{|c|c|c|c|c|c|}
\hline & $\begin{array}{l}\text { Avg. pre-post } \\
\text { difference in Arizona }\end{array}$ & $\begin{array}{l}\text { Avg. pre-post } \\
\text { difference } \\
\text { synth. AZ }\end{array}$ & $\begin{array}{l}\text { DD } \\
\text { estimates }\end{array}$ & $\begin{array}{l}\text { Rank, lowest } \\
\text { to highest }\end{array}$ & $\begin{array}{l}P \text { value from } \\
\text { one-tailed } \\
\text { test, } P(\Delta \leq \\
\Delta A Z)\end{array}$ \\
\hline \multicolumn{6}{|l|}{$\begin{array}{l}\text { A. Elementary } \\
\text { school }\end{array}$} \\
\hline $\begin{array}{l}\text { Number of } \\
\text { immigrant in } \\
\text { all schools }\end{array}$ & $-11,791$ & $-2,700$ & $-9,091$ & $1 / 44$ & 0.023 \\
\hline $\begin{array}{l}\text { Share of } \\
\text { immigrant in } \\
\text { all schools }\end{array}$ & -0.032 & -0.021 & -0.011 & $1 / 44$ & 0.023 \\
\hline $\begin{array}{l}\text { Share of } \\
\text { immigrant in } \\
\text { public schools } \\
\text { B. Secondary } \\
\text { school }\end{array}$ & -0.035 & -0.023 & -0.012 & $1 / 44$ & 0.023 \\
\hline $\begin{array}{l}\text { Number of } \\
\text { immigrant in } \\
\text { all schools }\end{array}$ & $-11,088$ & $-5,373$ & $-5,716$ & $3 / 44$ & 0.068 \\
\hline $\begin{array}{l}\text { Share of } \\
\text { immigrant in } \\
\text { all schools }\end{array}$ & -0.026 & -0.009 & -0.017 & $1 / 44$ & 0.023 \\
\hline $\begin{array}{l}\text { Share of } \\
\text { immigrant in } \\
\text { public schools } \\
\text { C. College }\end{array}$ & -0.028 & -0.009 & -0.019 & $1 / 44$ & 0.023 \\
\hline $\begin{array}{l}\text { Number of } \\
\text { immigrant in } \\
\text { all schools }\end{array}$ & 8,664 & 14,690 & $-6,025$ & $4 / 44$ & 0.091 \\
\hline $\begin{array}{l}\text { Share of } \\
\text { immigrant in } \\
\text { all schools }\end{array}$ & -0.010 & 0.005 & -0.015 & $1 / 44$ & 0.023 \\
\hline $\begin{array}{l}\text { Share of } \\
\text { immigrant in } \\
\text { public colleges }\end{array}$ & -0.013 & -0.001 & -0.012 & $3 / 44$ & 0.068 \\
\hline \multicolumn{6}{|c|}{$\begin{array}{l}\text { Notes: Estimates based on IPUMS 5\% } 2000 \text { Census and 2001-2015 American Community Survey (ACS). The pre-treatment period } \\
\text { is } 2000-2006 \text {, while the post-treatment period is 2007-2015. Synthetic Arizona is constructed by matching on the following: the } \\
\text { share of construction industry, the share of agricultural industry, the share of manufacturing industry, the share of foreign-born in } \\
\text { the state, the share of non-Hispanic whites in the population, the average age in the state, and the outcome variable itself from } \\
2001 \text { to } 2006 \text {. The one-tailed test of the significance of the difference-in-difference estimates uses the empirical distribution of the } \\
\text { placebo effect estimates of LAWA for states in the donor pool. California is excluded from the test because synthetic California } \\
\text { poorly matches actual California prior to } 2007\end{array}$} \\
\hline
\end{tabular}




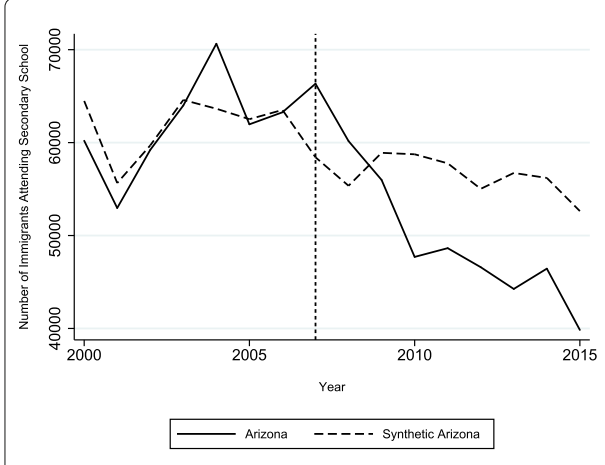

a

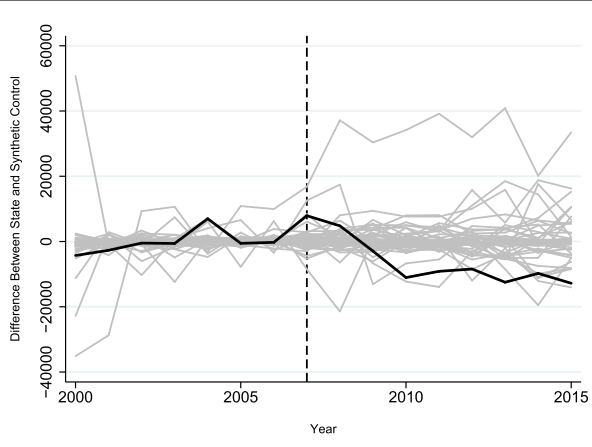

b

Fig. 2 LAWA and number of immigrants in secondary school. a Number of immigrants. b Permutation test

simulate a distribution of differences between each state in the donor pool and its synthetic control. ${ }^{6}$ Then, I examine whether Arizona shows a post-2007 difference relative to its synthetic control that is large compared to the whole distribution. If the difference of post-2007 Arizona relative to its synthetic control is not large compared to the empirical distribution of placebo effect estimates, it is quite likely that the difference between Arizona and its synthetic control after 2007 occurs simply by chance.

Figure $1 \mathrm{~b}$ graphically displays the year-by-year difference in the number of foreign-born elementary school students between each state in the donor pool, including Arizona, and its synthetic control. The difference for each of the donor states is displayed with gray lines, while the difference for Arizona is displayed with a thick black line. The vertical dash line indicates the year of 2007. The figure shows that the decline in the size of immigrant student population in elementary school in Arizona relative to its synthetic control after 2007 is much larger compared to other placebo runs, suggesting the probability that this decline occurring simply by chance is rather small. Indeed, the probability that we observe a difference-in-differences estimate that is as large as Arizona is 0.023 (panel A of Table 1$){ }^{7}$

In Figs. 2 and 3, I repeat the analysis above on the size of foreign-born student population in secondary school and college. The figures show that the size of immigrant student

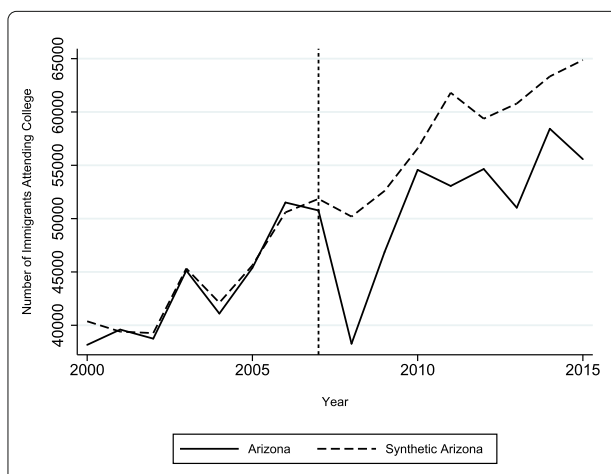

a

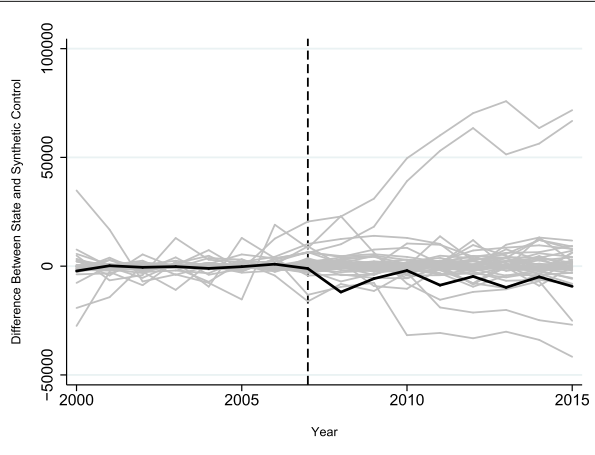

b

Fig. 3 LAWA and number of immigrants in college. a Number of immigrants. b Permutation test 


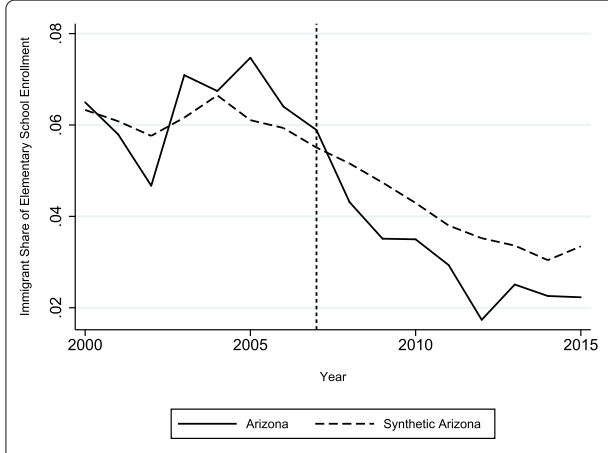

a

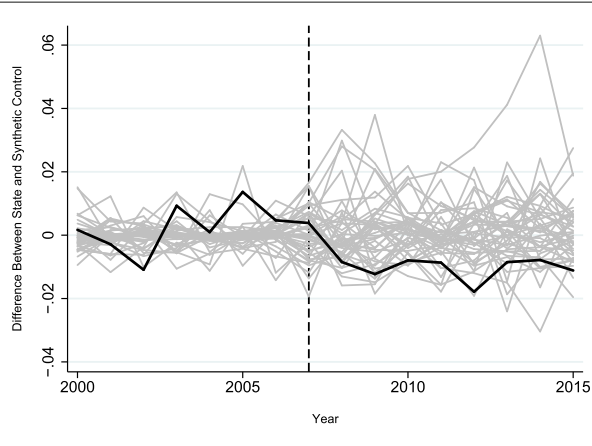

b

Fig. 4 LAWA and share of immigrants in elementary school. a Share of immigrants. b Permutation test

population in both secondary school and college in Arizona falls relative to its synthetic control after LAWA was implemented. The difference-in-difference estimates show that there would be 5716 more foreign-born secondary school students and 6025 more college students in the absence of LAWA (panel B and C of Table 1), and these results are significant at $5 \%$ level. These declines represent a reduction of approximately $9 \%$ and $14 \%$ of the pre-LAWA size of foreign-born secondary and college student population, respectively.

Figures 4, 5 and 6 show the results of the analysis of the impact of LAWA on foreignborn students in terms of the share of the total enrollment. Similar to before, the figures illustrate that the share of foreign-born students across Arizona's educational system declines relative to its synthetic control. The difference-in-differences estimates show that LAWA led to a decline of approximately 1.1 percentage points of the share of foreign-born students in elementary school, while the effect is larger for secondary school and college students at 1.7 and 1.5 percentage points, respectively (panel A to C of Table 1 ). These results are statistically significant at the $5 \%$ level.

As noted in the previous section, there is a concern that the decline in the size of foreign-born population in higher education may be caused by the Public Program Eligibility Act (PPEA), which requires verification of immigration status of college students applying for any financial assistance paid by the state funds, instead of LAWA. Considering that I define the pretreatment period as the year 2000 through 2006, the

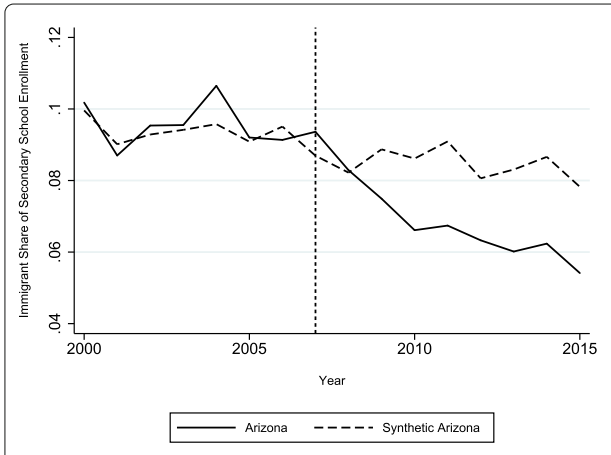

a

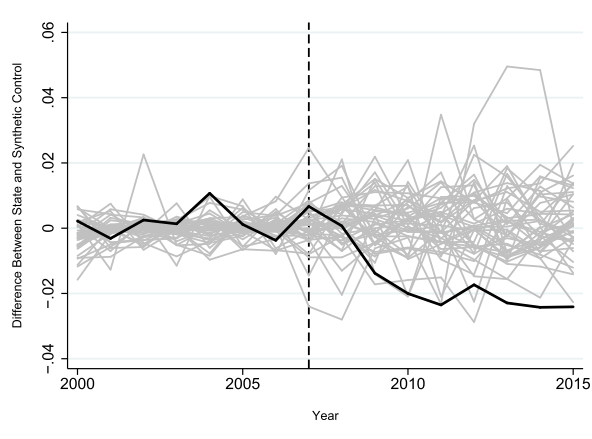

b

Fig. 5 LAWA and share of immigrants in secondary school. a Share of immigrants. b Permutation test 


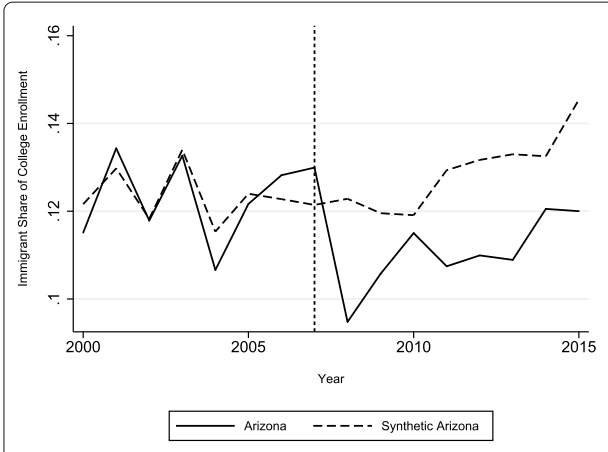

a

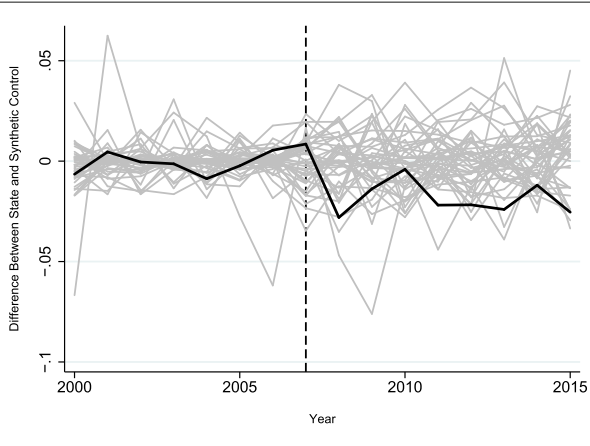

b

Fig. 6 LAWA and share of immigrants in college. a Share of immigrants. b Permutation test

impact of PPEA, which became effective at the very end of 2006, should be observed in 2007. However, there is no evidence that the foreign-born share of college enrollment declines in Arizona relative to its synthetic control in 2007 (Figs. 3 and 6). The sharp decline is observed in 2008, the year in which LAWA was implemented in Arizona. Considering that the timing of the decline in the relative size of college foreign-born students does not match to the year in which PPEA should have taken effect, it is quite unlikely that the declines observed in Figs. 3 and 6 are caused by PPEA.

Figures 7, 8 and 9 show the results of analyzing the impact of LAWA on the share of immigrant students in public school across the three educational levels (i.e., elementary, secondary, and college) in Arizona. Unsurprisingly, the results are quite similar as before. The difference-in-difference estimates show that LAWA led to a decline of the share of foreign-born students in public elementary and secondary schools by approximately 1.2 and 1.9 percentage points, respectively, while the decline is approximately 1.2 percentage points in public colleges (Table 1).

To summarize, the analyses show that LAWA reduces the share of foreign-born students across Arizona's education system after its adoption in 2007. This result suggests that LAWA can serve as a natural experiment to examine how a stricter immigration policy would affect college enrollment rates among US-born individuals and the share of native students attending private schools.

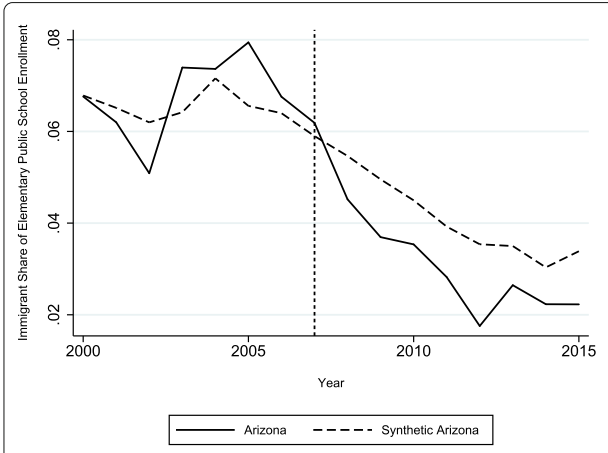

a

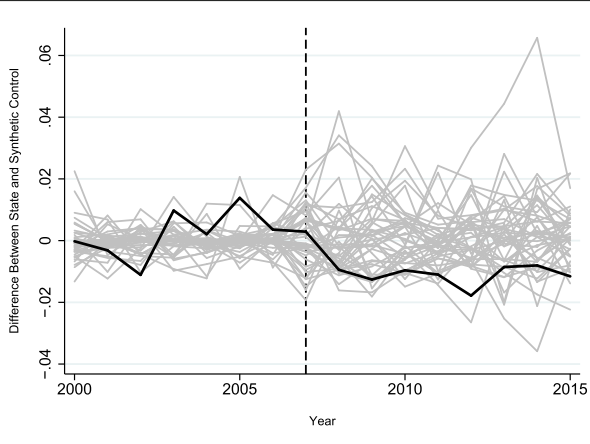

b

Fig. 7 LAWA and share of immigrants in public elementary school. a Share of immigrants. b Permutation test 


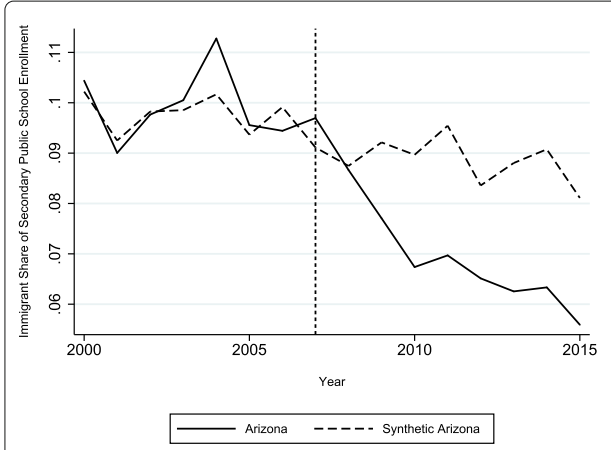

a

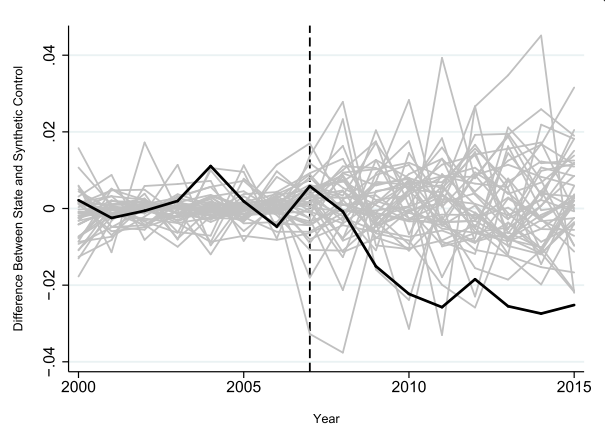

b

Fig. 8 LAWA and share of immigrants in public secondary school. a Share of immigrants. b Permutation test

\subsection{Does LAWA improve natives' college enrollment rates?}

In the previous subsection, I show that the size of the foreign-born student population across Arizona's educational system falls dramatically due to the implementation of LAWA, which allows me to examine whether college enrollment rates among US-born individuals are affected by the decline of foreign-born population in Arizona. It should be noted that the $p$ value testing for the analysis in this subsection is based on a two-tailed test because the impact of LAWA on natives' college enrollment rates is theoretically ambiguous. The decrease of foreign-born students in higher education may increase the enrollment rate of US-born individuals by increasing academic resources/number of admission slots available to them, while less competition with immigrants in the low-skilled labor market would incentivize natives to enter the labor market instead of pursuing higher education.

Figure 10a shows the enrollment rate of natives in higher education for those who are likely to be in college (18 to 24 years old) in Arizona and its synthetic control. There is no evidence that overall natives' college enrollment rate is lower in Arizona relative to its synthetic control after the adoption of LAWA. The permutation test in Fig. 10b corroborates this finding. The difference-in-difference estimate suggests that college enrollment rate among US-born individuals declines by 1 percentage points due to LAWA, but this decline is not statistically significant (Table 2). Therefore, there is no evidence that LAWA

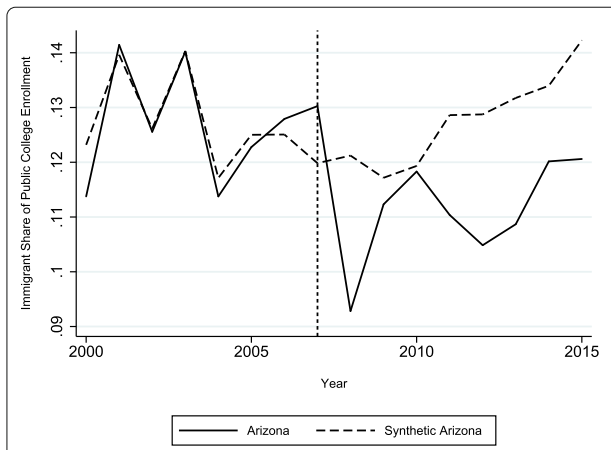

a

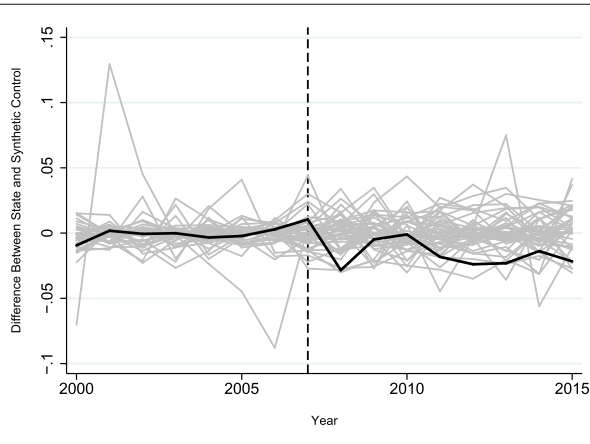

b

Fig. 9 LAWA and share of immigrants in public college. a Share of immigrants. b Permutation test 


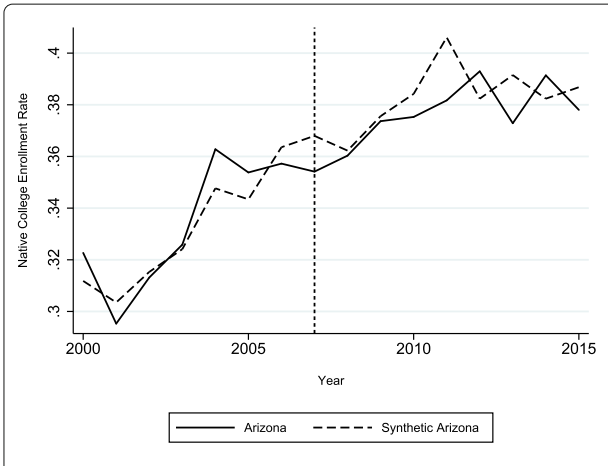

a

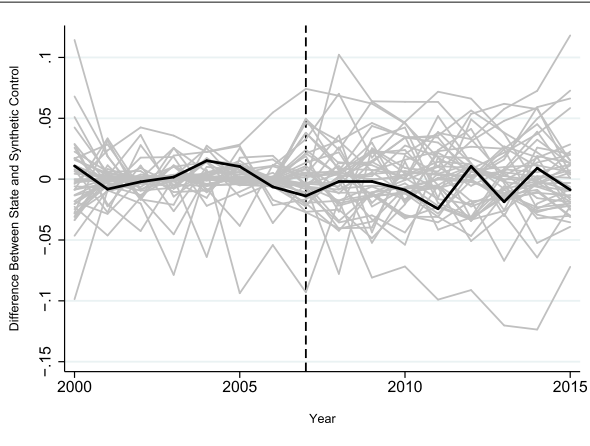

b

Fig. 10 Natives' college enrollment rate (18-24 years old). a Enrollment rate. b Permutation test

altered natives' college enrollment rates for those who are likely to be in college after its adoption in 2007.8

A study by Hoxby (1998) argues that immigrants crowd disadvantaged natives out of higher education because the two groups often compete for similar academic resources, such as grants that institutions make to needy students. The author finds evidence that immigrants crowd black and Hispanic natives out of colleges. Considering that LAWA "freed up" more resources to be distributed among disadvantaged natives, it is possible that LAWA would lead to an improvement in college enrollment rates among these groups. In Figs. 11 and 12, I repeat the analysis above for black and Hispanic natives. Looking at the figures, there is no evidence that LAWA improves college enrollment rates of US-born blacks or Hispanics. The sign of difference-in-difference estimates is negative, suggesting that LAWA reduces college enrollment rates for blacks and Hispanic natives, but this decline is not statistically significant (Table 2). A similar result is also observed among white non-Hispanic natives (Fig. 13).

Overall, I find no evidence that the adoption of LAWA in Arizona improves the enrollment rate of US-born individuals in higher education, and this result holds among black or Hispanic natives, who are usually coming from a disadvantaged background.

\subsection{LAWA and proportion of US-born students attending private schools}

In this subsection, I examine whether the implementation of LAWA lowers the share of natives attending private schools in Arizona. As noted by Betts and Fairlie (2003), a higher

Table $\mathbf{2}$ LAWA and natives' college enrollment rates (18-24 years old)

\begin{tabular}{lllll}
\hline & $\begin{array}{l}\text { Avg. pre-post } \\
\text { difference in } \\
\text { Arizona }\end{array}$ & $\begin{array}{l}\text { Avg. pre-post } \\
\text { difference synth. } \\
\mathrm{AZ}\end{array}$ & $\begin{array}{l}\text { DD } \\
\text { estimates }\end{array}$ & $\begin{array}{l}P \text { value from two- } \\
\text { tailed test, } P(|\Delta| \geq \\
|\Delta A Z|)\end{array}$ \\
\hline $\begin{array}{l}\text { Overall } \\
\text { By race: }\end{array}$ & 0.043 & 0.052 & -0.010 & 0.578 \\
Black & 0.041 & 0.087 & & \\
Hispanic & 0.053 & 0.077 & -0.047 & 0.311 \\
White non-Hispanic & 0.051 & 0.061 & -0.023 & 0.511 \\
\hline
\end{tabular}

Notes: Estimates based on IPUMS 5\% 2000 Census and 2001-2015 American Community Survey (ACS). The pre-treatment period is 2000-2006, while the post-treatment period is 2007-2015. Synthetic Arizona is constructed by matching on the following: the share of construction industry, the share of agricultural industry, the share of manufacturing industry, the share of foreign-born in the state, the share of non-Hispanic whites in the population, the average age in the state, and the outcome variable itself from 2001 to 2006. The two-tailed test of the significance of the difference-in-difference estimates use the empirical distribution of the placebo effect estimates of LAWA for states in the donor pool 


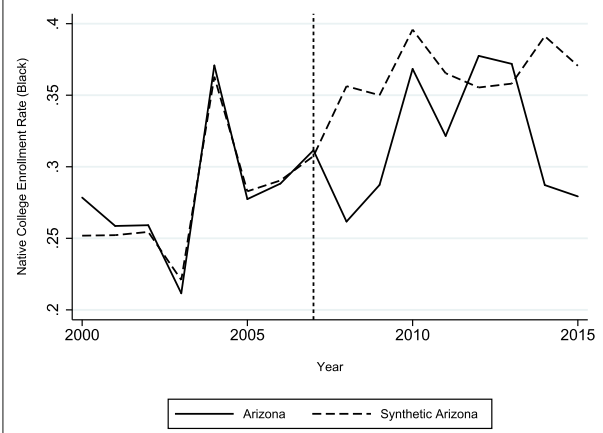

a

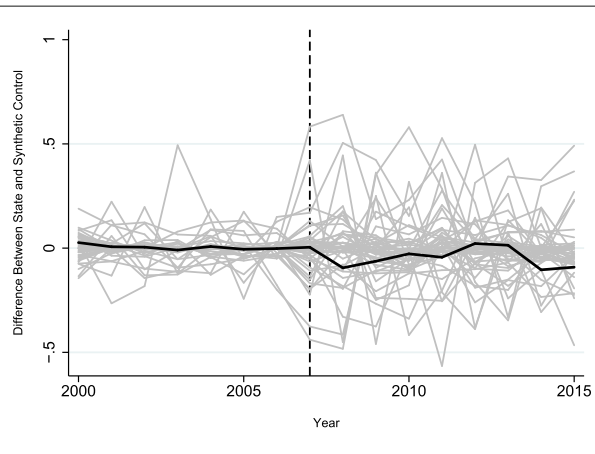

b

Fig. 11 Natives' college enrollment rate (18-24 years old, black). a Enrollment rate. b Permutation test

proportion of US-born students attending private schools may reduce support for public education, leading to the deterioration of the quality of public schools. Therefore, there is a need to understanding of whether a policy such as LAWA can increase the share of natives attending public school.

Figure 14 shows the graphical analysis for the share of natives in elementary education attending private schools. There is no evidence that the proportion of US-born students in elementary education attending private schools in Arizona falls relative to its synthetic control. The difference-in-differences estimate shows that LAWA reduces the share of natives in elementary education attending private schools by approximately by 0.3 percentage points, but this reduction is not statistically significant (Table 3).

In Figs. 15 and 16, I repeat the analysis above for the share of natives in secondary education and college attending private schools. There is evidence that LAWA led to a decline in the share of US-born students attending private schools in these education groups, but from looking at the permutation test figures, it is unlikely that this decline is statistically significant. The difference-in-difference estimates show that LAWA reduces the share of natives attending private school in secondary education and college by approximately 0.8 and 1.3 percentage points, respectively, but these reductions are not statistically significant.

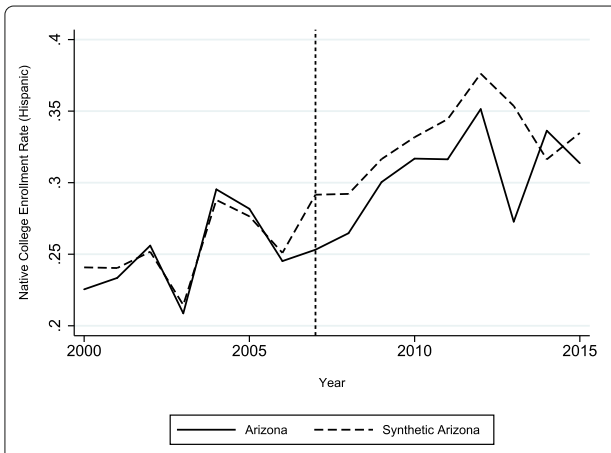

a

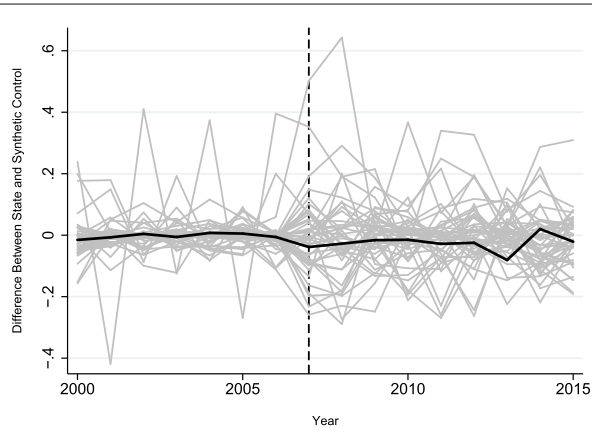

b

Fig. 12 Natives' college enrollment rate (18-24 years old, Hispanic). a Enrollment rate. b Permutation test 


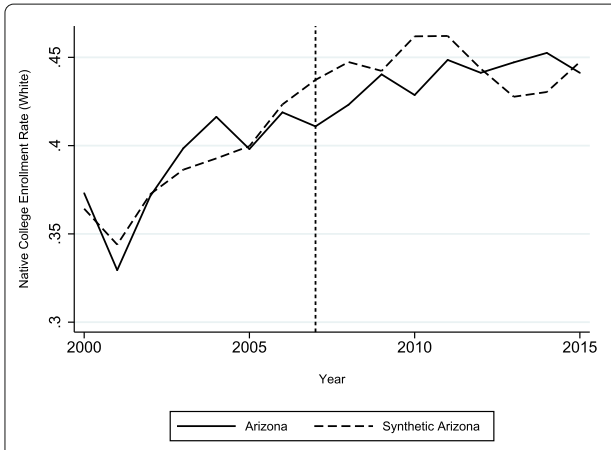

a

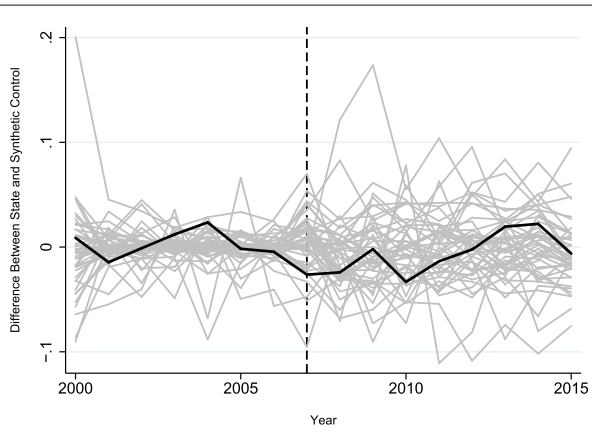

b

Fig. 13 Natives' college enrollment rate (18-24 years old, white non-Hispanic). a Enrollment rate. b Permutation test

The literature on the effect of immigration on native flight stems from earlier studies that examine the response of white students to the influx of black and minority students [e.g.,(Conlon and Kimenyi 1991; Fairlie and Resch 2002)]. These studies argue that "white flight" may be driven by "irrational prejudice" as well as perceived lower school quality in the school with a higher fraction of minority students. As such, there might be a stronger response among white students to move to private schools when there is an influx of immigrant students. To find out if this is indeed the case, I repeat the analysis above by race. ${ }^{9}$ The results are reported on Table 3 and Figs. 17, 18 and 19 as well as Appendix Figs. 20, 21, 22, 23, 24 and 25. Although there is no evidence of a statistically significant decline in the share of US-born black and Hispanic students attending private schools at all educational level in response to LAWA, the analysis shows that LAWA reduced the proportion of native white non-Hispanic student in higher education attending private colleges. The difference-in-differences estimate shows that the share of US-born students in college attending private schools in Arizona declines by approximately 2.7 percentage points, and this result is marginally significant at $10 \%$ level. As there are approximately $19 \%$ of US-born white non-Hispanic student in college attending private schools before LAWA, this decline corresponds to $14 \%$ decrease relative to its pre-LAWA average.

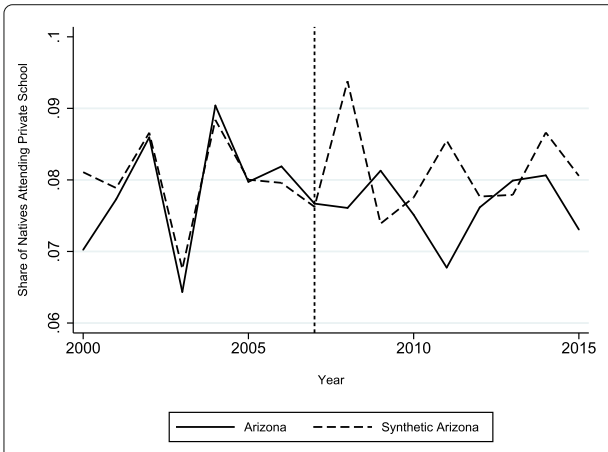

a

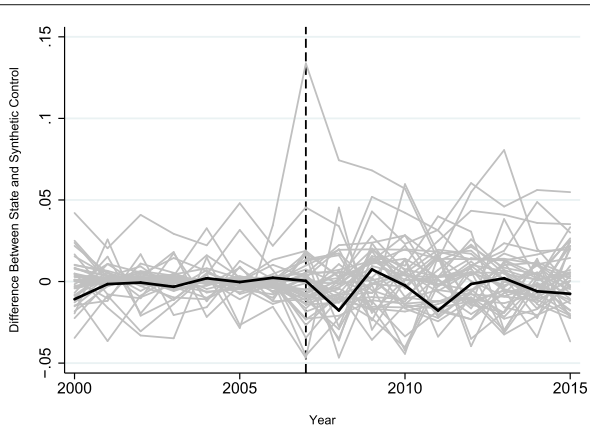

b

Fig. 14 Share of natives in elementary education attending private school. a Share of native. b Permutation test 
Table 3 LAWA and share of natives attending private school

\begin{tabular}{|c|c|c|c|c|c|}
\hline & $\begin{array}{l}\text { Avg. pre-post } \\
\text { difference in } \\
\text { Arizona }\end{array}$ & $\begin{array}{l}\text { Avg. pre-post } \\
\text { difference } \\
\text { synth. AZ }\end{array}$ & $\begin{array}{l}\text { DD } \\
\text { estimates }\end{array}$ & $\begin{array}{l}\text { Rank (lowest to } \\
\text { highest) }\end{array}$ & $\begin{array}{l}P \text { value from } \\
\text { one-tailed test, } \\
P(\Delta \leq \Delta \mathrm{AZ})\end{array}$ \\
\hline \multicolumn{6}{|l|}{$\begin{array}{l}\text { A. Elementary } \\
\text { school }\end{array}$} \\
\hline $\begin{array}{l}\text { Share of native } \\
\text { in elementary } \\
\text { school attending } \\
\text { private school } \\
\text { By race: }\end{array}$ & -0.002 & 0.001 & -0.003 & $21 / 45$ & 0.467 \\
\hline White non- & 0.002 & 0.007 & -0.005 & $17 / 45$ & 0.378 \\
\hline $\begin{array}{l}\text { Black } \\
\text { Hispanic }\end{array}$ & $\begin{array}{l}0.010 \\
0.004\end{array}$ & $\begin{array}{l}0.001 \\
0.003\end{array}$ & $\begin{array}{l}0.009 \\
0.001\end{array}$ & $\begin{array}{l}32 / 45 \\
30 / 45\end{array}$ & $\begin{array}{l}0.711 \\
0.667\end{array}$ \\
\hline $\begin{array}{l}\text { B. Secondary } \\
\text { school }\end{array}$ & & & & & \\
\hline $\begin{array}{l}\text { Share of native in } \\
\text { secondary } \\
\text { school attending } \\
\text { private school } \\
\text { By race: }\end{array}$ & -0.002 & 0.006 & -0.008 & $14 / 45$ & 0.311 \\
\hline $\begin{array}{l}\text { White non- } \\
\text { Hisnanir }\end{array}$ & 0.005 & 0.010 & -0.005 & $15 / 44$ & 0.341 \\
\hline $\begin{array}{l}\text { Black } \\
\text { Hispanic }\end{array}$ & $\begin{array}{l}0.021 \\
-0.001\end{array}$ & $\begin{array}{l}0.001 \\
0.006\end{array}$ & $\begin{array}{l}0.020 \\
-0.007\end{array}$ & $\begin{array}{l}38 / 45 \\
18 / 45\end{array}$ & $\begin{array}{l}0.844 \\
0.400\end{array}$ \\
\hline $\begin{array}{l}\text { Share of native } \\
\text { in college } \\
\text { attending } \\
\text { private school } \\
\text { By race: }\end{array}$ & -0.012 & 0.001 & -0.013 & $17 / 45$ & 0.378 \\
\hline \multirow{2}{*}{$\begin{array}{l}\text { By race: } \\
\text { White non- } \\
\text { Hispanic } \\
\text { Black } \\
\text { Hispanic }\end{array}$} & -0.010 & 0.017 & -0.027 & $4 / 44$ & 0.091 \\
\hline & $\begin{array}{l}0.038 \\
-0.010\end{array}$ & $\begin{array}{l}0.008 \\
-0.012\end{array}$ & $\begin{array}{l}0.030 \\
0.003\end{array}$ & $\begin{array}{l}37 / 45 \\
26 / 45\end{array}$ & $\begin{array}{l}0.822 \\
0.578\end{array}$ \\
\hline
\end{tabular}

Notes: Estimates based on IPUMS 5\% 2000 Census and 2001-2015 American Community Survey (ACS). The pre-treatment period is 2000-2006, while the post-treatment period is 2007-2015. Synthetic Arizona is constructed by matching on the following: the share of construction industry, the share of agricultural industry, the share of manufacturing industry, the share of foreign-born in the state, the share of non-Hispanic whites in the population, the average age in the state, and the outcome variable itself from 2001 to 2006. The one-tailed test of the significance of the difference-in-difference estimates use the empirical distribution of the placebo effect estimates of LAWA for states in the donor pool. The rankings for white non-Hispanics analyses are out of 44 because Synthetic District of Columbia (D.C.) poorly matches actual D.C. prior to 2007 in these analyses and therefore was excluded from the test

\section{Conclusion}

In recent decades, the USA has admitted a large number of foreign-born students into its educational system. At the same time, there are concerns that the presence of foreign-born students would adversely impact the educational achievement of nativeborn students and incentivize them to move to private schools where there are fewer

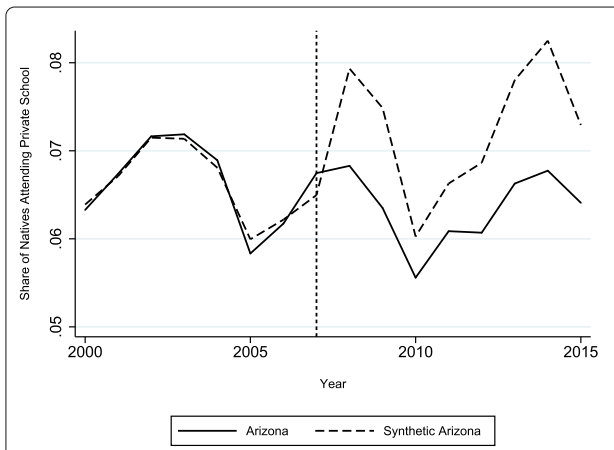

a

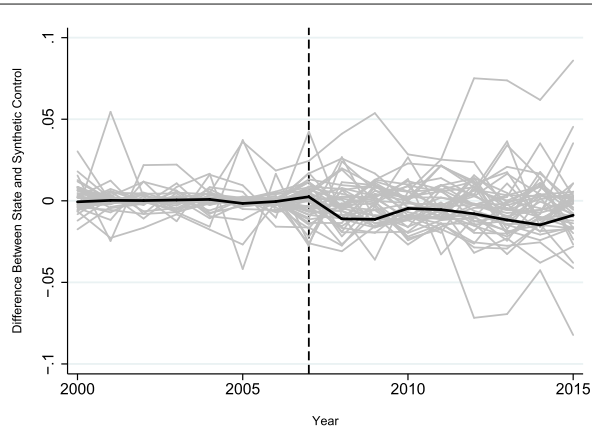

b

Fig. 15 Share of natives in secondary education attending private school. a Share of native. $\mathbf{b}$ Permutation test 


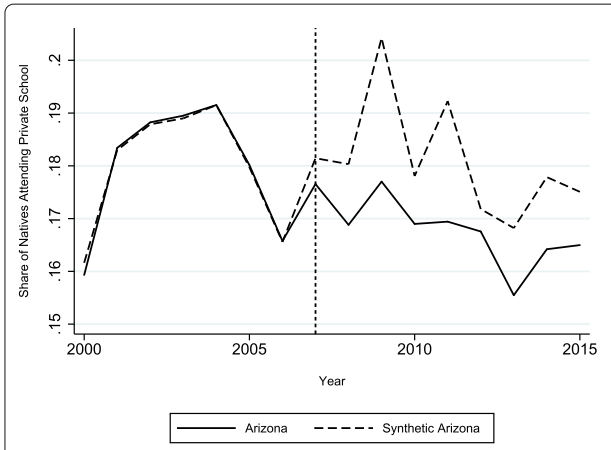

a

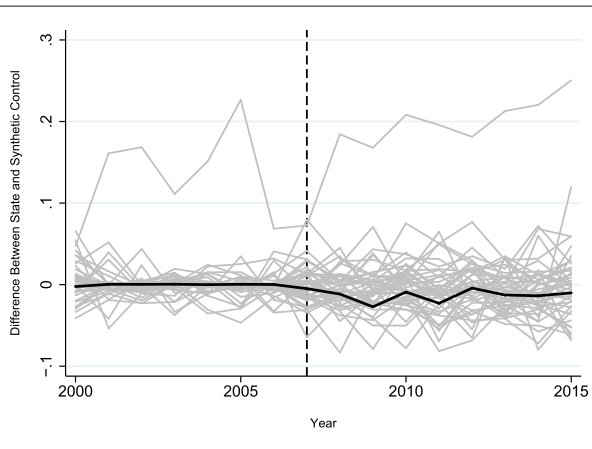

b

Fig. 16 Share of natives in college attending private school. a Share of native. $\mathbf{b}$ Permutation test

immigrant students. Prior studies have reported that foreign-born students "crowd out" natives from colleges and graduate programs (Hoxby 1998; Borjas 2004), while the presence of students with limited English proficiency presents a barrier to learning in US schools (Chin et al. 2013; Diette and Uwaifo Oyelere 2014).

In this paper, I attempt to extend our understanding of how stricter immigration policies such as Legal Arizona Workers Act (LAWA) may affect college enrollment and public-private school choice of natives. The analysis shows that the share of immigrants across Arizona's educational system declines significantly due to LAWA: the share of foreign-born students in public elementary and secondary school in Arizona would be higher by approximately 1.1 and 1.7 percentage points, respectively, in the absence of LAWA. Similarly, the share of foreign-born college students in Arizona declined significantly by 1.5 percentage points due to LAWA. Despite this decline, there is no evidence that natives' college enrollment rates are statistically significantly affected, even among black and Hispanic natives, who are usually coming from a disadvantaged background.

This result might seem contradictory to the findings by Hoxby (1998) and Borjas (2004), who found that immigrant students crowd natives out from colleges and graduate programs. It is worth noting that the result presented in this study does not

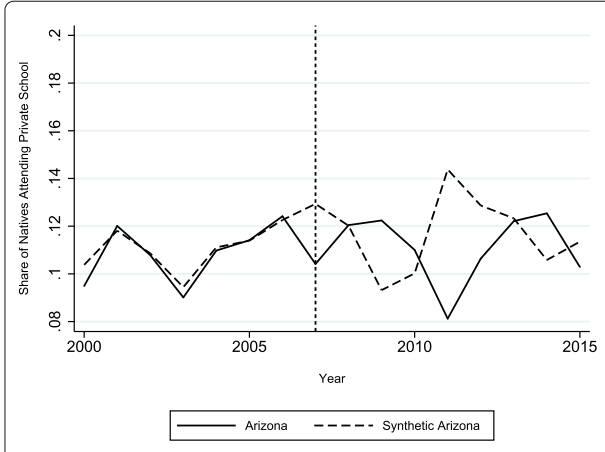

a

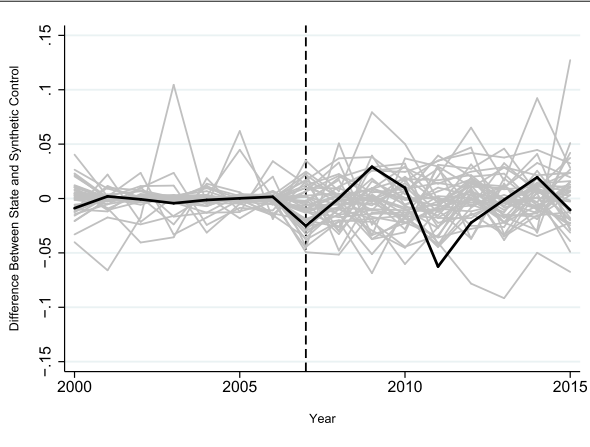

b

Fig. 17 Share of native in elementary education attending private school (white non-Hispanic). a Share of native. b Permutation test 


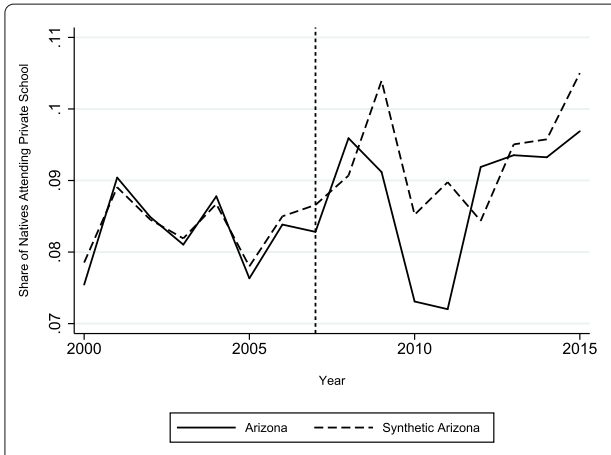

a

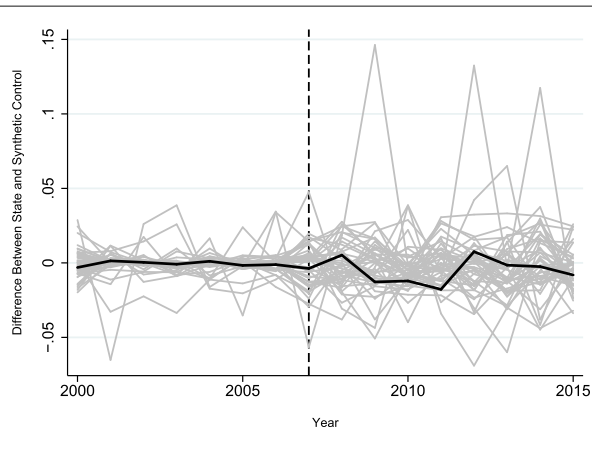

b

Fig. 18 Share of native in secondary education attending private school (white non-Hispanic). a Share of native. $\mathbf{b}$ Permutation test

necessarily imply that there is no crowding out effect. LAWA led to a decline of both foreign-born student population and low-skilled immigrant workers, in which the latter increased the returns for natives to enter the labor market directly and reduced the benefits of going to college. Indeed, a study by Bohn et al. (2015) found that the earnings of low-skilled native men in Arizona increased on average following LAWA. Therefore, it is likely that the effect observed in this study is a net effect. In other words, LAWA did not only increase the admission slots available for natives in colleges but also making it less attractive for them to enter higher education at the same time.

I also found that LAWA reduced the proportion of US-born white non-Hispanics students in higher education attending private colleges by approximately 2.7 percentage points. This finding is consistent with "native flight" hypothesis, in which an influx of immigrant students induces native households to enroll their children in private schools. Although a few other studies have also documented results supporting this hypothesis (Betts and Fairlie 2003; Gerdes 2013; Farre et al. 2018), the mechanisms driving this relationship are still unclear. Is native flight caused by "irrational prejudice" toward immigrant students? Or is there a valid concern regarding school quality that causes native households to enroll their children in private schools in response to an inflow of immigrant students? Future research that can

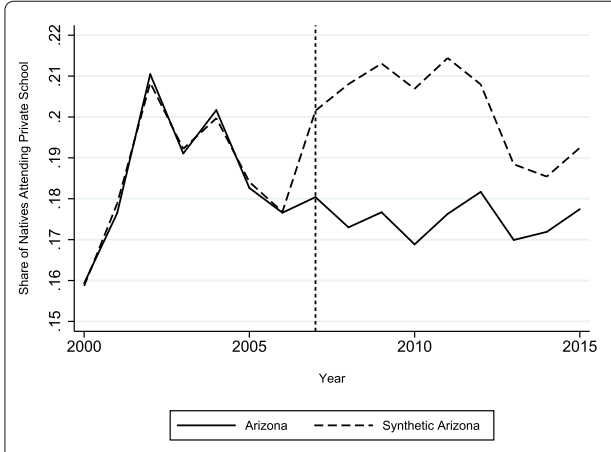

a

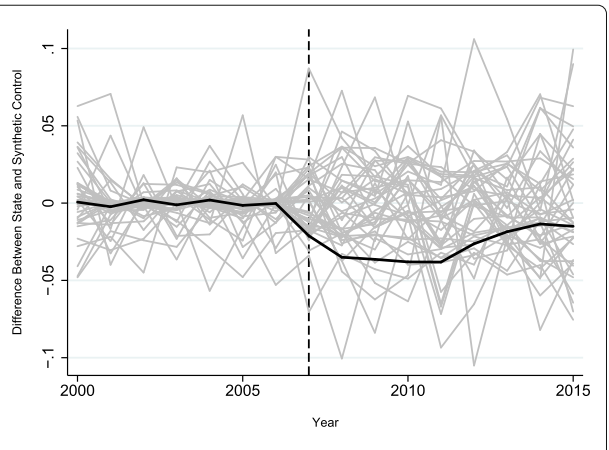

b

Fig. 19 Share of native in college attending private school (white non-Hispanic). a Share of native. b Permutation test 
explain the mechanisms behind native flight would certainly advance the knowledge on this topic.

\section{Endnotes}

${ }^{1}$ I used STATA's default option for constructing matrix $V$. The default option uses a regression-based method as described in Kaul et al. (2015) in which matching variables that are strong predictors of the dependent variable are given more weight.

${ }^{2}$ I did not use all years of pretreatment outcome as predictors because it would eliminate all other predictors' effects in the construction of synthetic control. As shown by Kaul et al. (2015), this may lead to bias in the synthetic Arizona outcome values in post-treatment period.

${ }^{3}$ PPEA does not restrict colleges in Arizona from admitting undocumented students nor require them to report students who are unable to prove that they are legally here in the USA. It is worth noting that under PPEA, undocumented students are still eligible for scholarship/financial aid funded by non-state sources.

${ }^{4}$ I defined the pretreatment period in which Arizona and its synthetic control to be matched as closely as possible as the year 2000 through 2006. Therefore, we should see a decline in the foreign-born share of college enrollment in Arizona relative to its synthetic control in 2007 if PPEA had an impact.

${ }^{5}$ The weights used to construct synthetic Arizona for all analyses in this paper are reported on Appendix Table 4, 5 and 6. Throughout this paper, I defined an individual attending elementary school if he/she is in kindergarten or in grade 1 through 4 . Similarly, I defined an individual attending secondary school if he/she is in grade 5 through 12 .

${ }^{6}$ Note that in identifying synthetic control groups for each of the remaining states in the donor pool, I excluded Arizona as the potential donor state. As noted by Peri and Yasenov (2018) in their Mariel's work, this specification choice would avoid contaminating the control group if there is any impact of LAWA in Arizona.

${ }^{7}$ Based on a suggestion by Abadie et al. (2010) to exclude placebo runs with a poor fit prior to treatment period, I excluded California from the permutation test for all analyses in this subsection because synthetic California poorly matches actual California prior to 2007. Note that California is still used as a potential control state in the donor pool to create the synthetic control. The results hold qualitatively when California is included in permutation test.

${ }^{8}$ For robustness check, I also analyzed whether overall natives' college enrollment rates-without restricting it only to 18 to 24 years old-is affected by the passage of LAWA. All the results in this section hold qualitatively. Similarly, all the results in this section also hold qualitatively when I examine the impact of LAWA on natives' college enrollment rates among 19 to 20 -year-olds.

${ }^{9}$ For white non-Hispanics analyses in this subsection, I excluded District of Columbia (D.C.) from the permutation test because synthetic D.C. poorly matches actual D.C. prior to 2007. Note that D.C. is still used as a potential control state in the donor pool to create the synthetic control. The result holds qualitatively when D.C. is included in permutation test.

\section{Appendix}




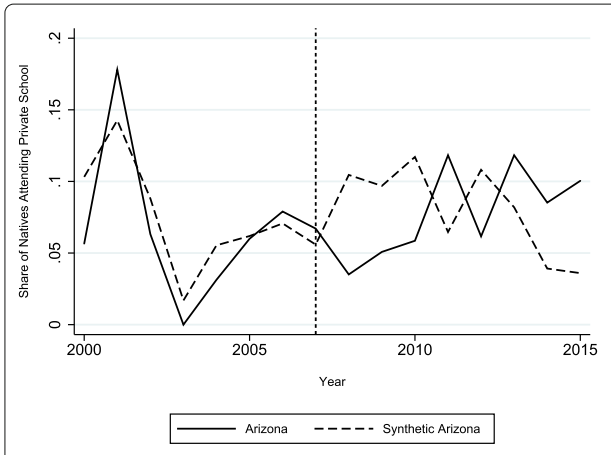

a

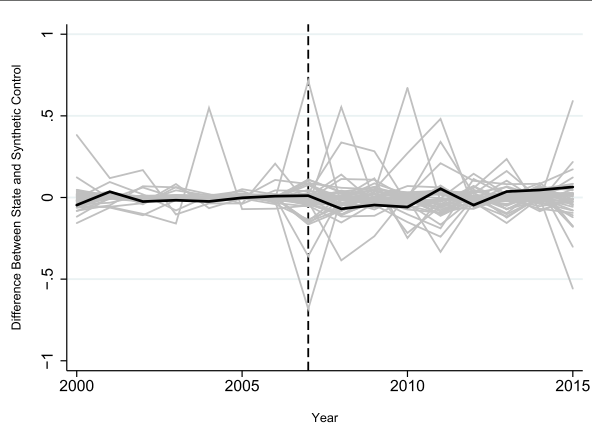

b

Fig. 20 Share of native in elementary education attending private school (black). $\mathbf{a}$ Share of native. $\mathbf{b}$ Permutation test

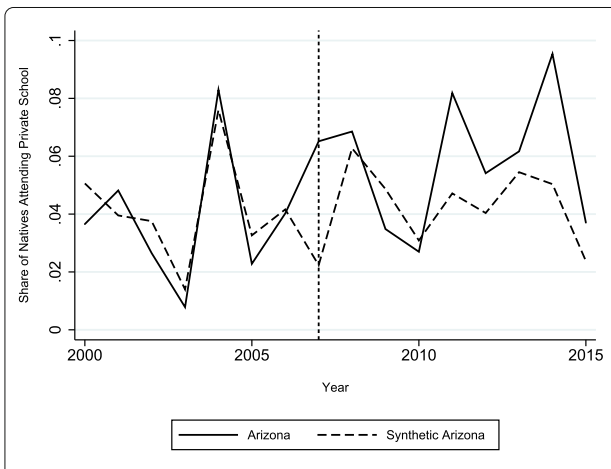

a

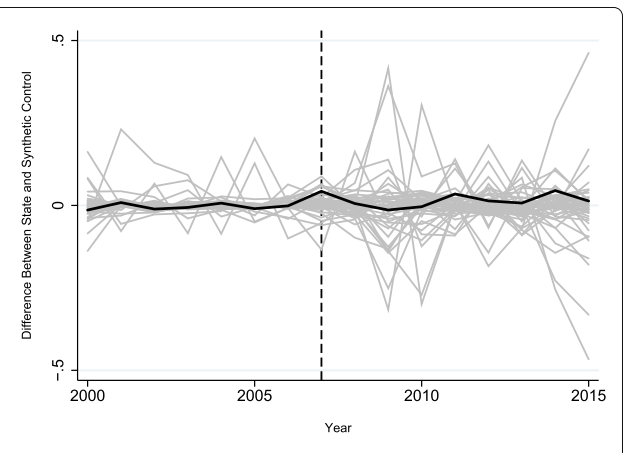

b

Fig. 21 Share of native in secondary education attending private school (black). a Share of native. $\mathbf{b}$ Permutation test

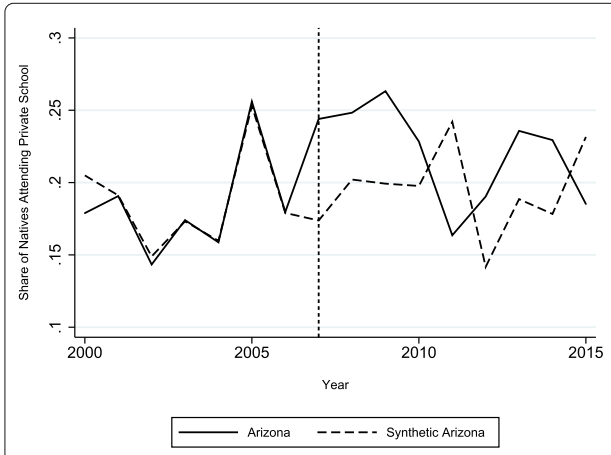

a

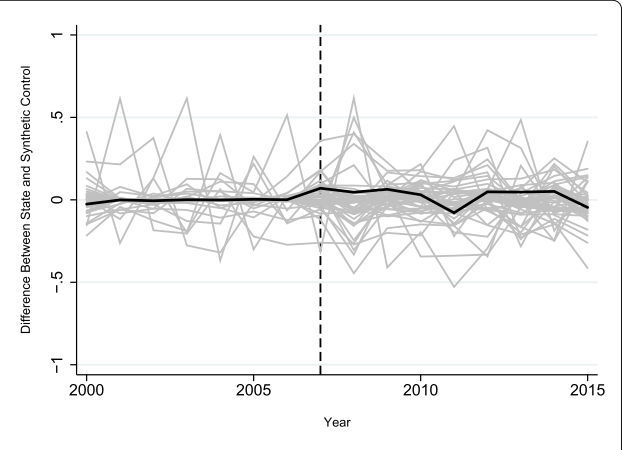

b

Fig. 22 Share of native in college attending private school (black). a Share of native. b Permutation test 


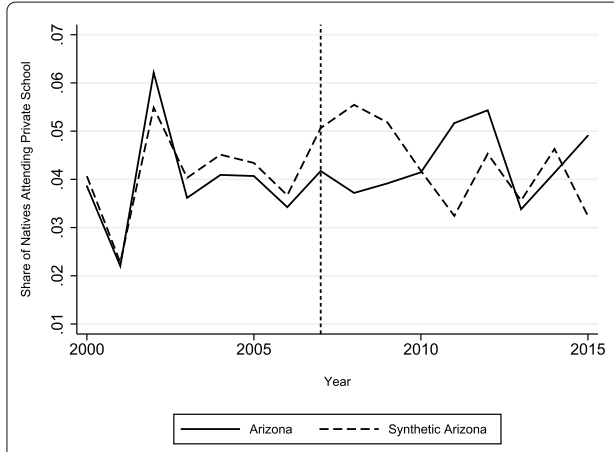

a

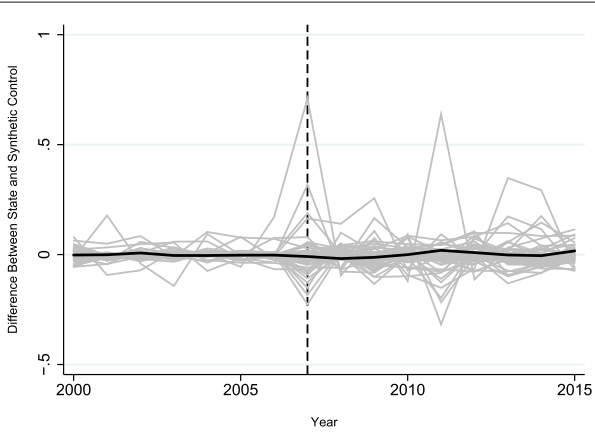

b

Fig. 23 Share of native in elementary education attending private school (Hispanic). a Share of native. $\mathbf{b}$ Permutation test

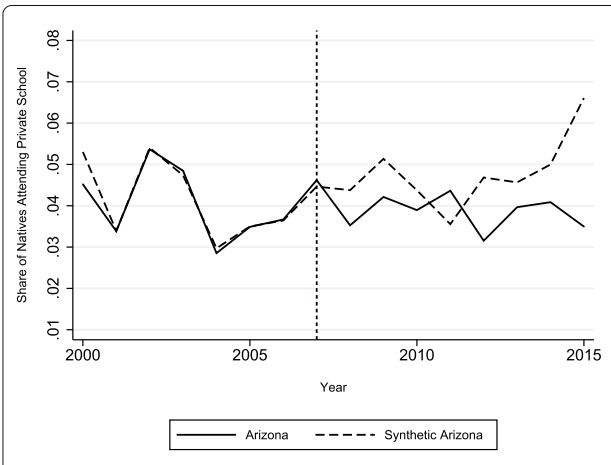

a

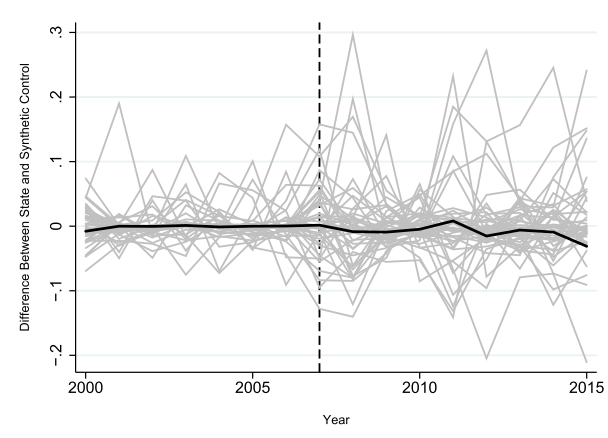

b

Fig. 24 Share of native in secondary education attending private school (Hispanic). a Share of native. $\mathbf{b}$ Permutation test

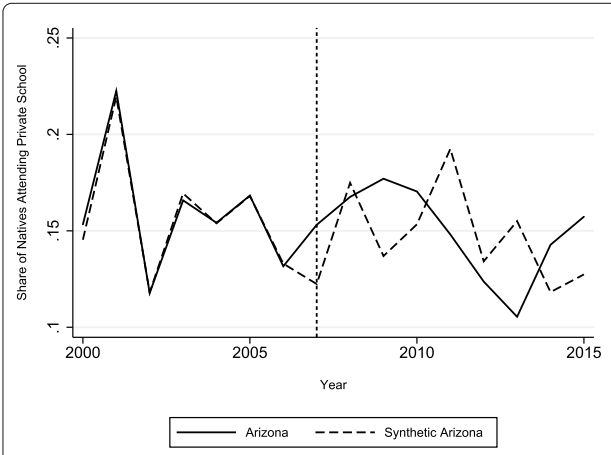

a

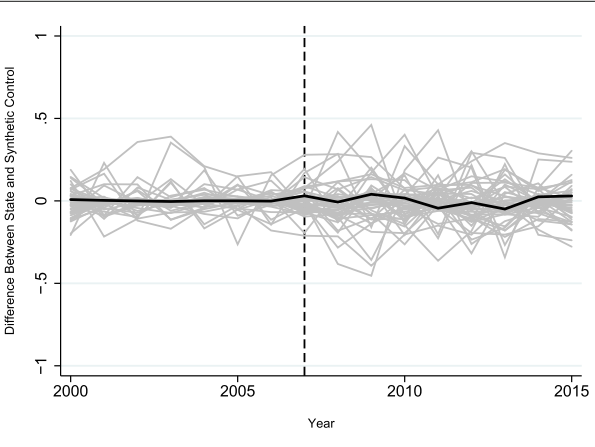

b

Fig. 25 Share of native in college attending private school (Hispanic). a Share of native. b Permutation test 


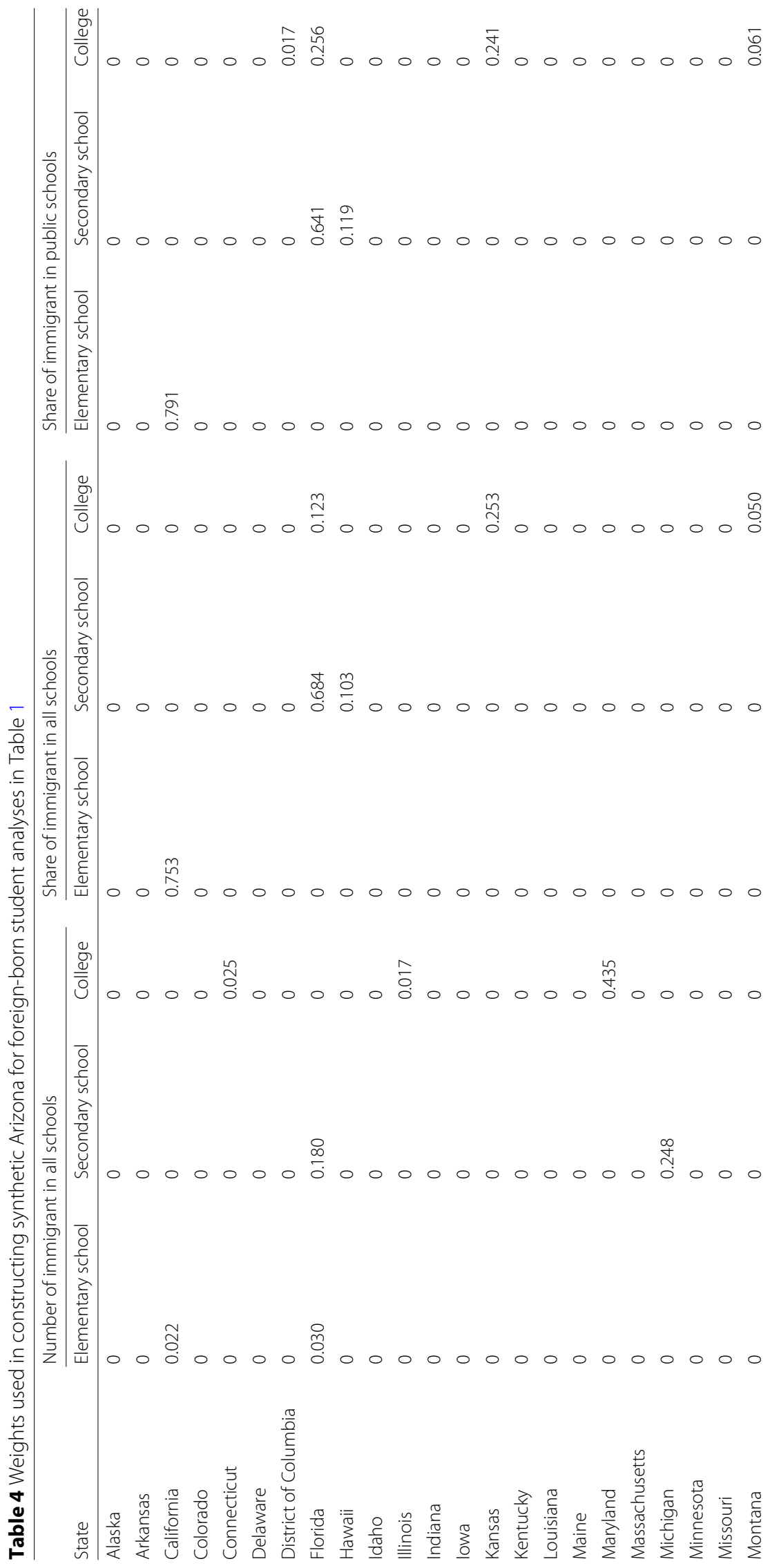




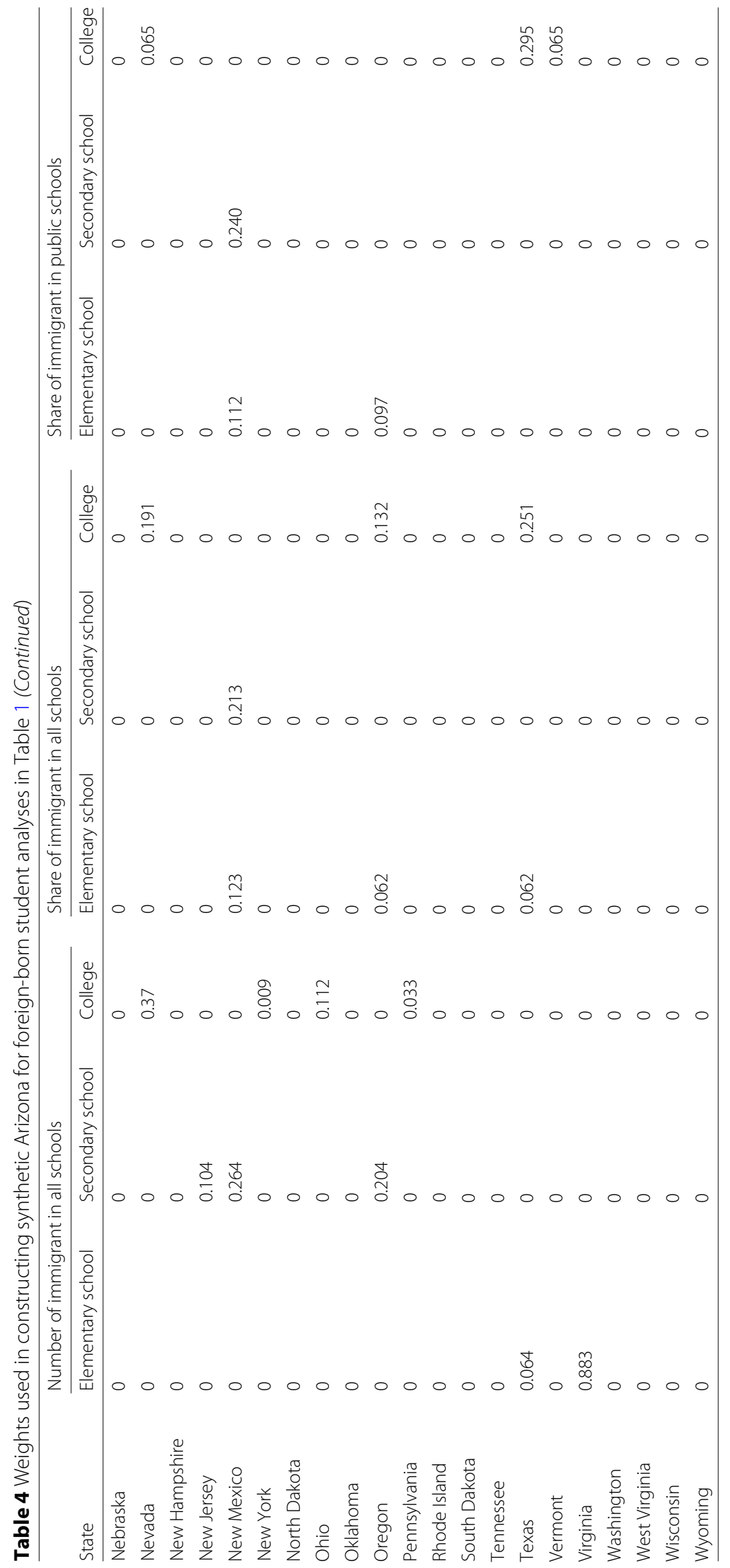


Table 5 Weights used in constructing synthetic Arizona for college enrollment rates analyses in Table 2

\begin{tabular}{|c|c|c|c|c|}
\hline State & Overall & Black & Hispanics & White non-Hispanics \\
\hline Alaska & 0 & 0.052 & 0 & 0 \\
\hline Arkansas & 0 & 0 & 0 & 0 \\
\hline California & 0.199 & 0 & 0 & 0.224 \\
\hline Colorado & 0 & 0 & 0.365 & 0.049 \\
\hline Connecticut & 0 & 0 & 0 & 0 \\
\hline Delaware & 0 & 0 & 0 & 0 \\
\hline District of Columbia & 0 & 0 & 0 & 0 \\
\hline Florida & 0 & 0 & 0 & 0 \\
\hline Hawaii & 0 & 0 & 0 & 0.093 \\
\hline Idaho & 0.052 & 0 & 0 & 0.133 \\
\hline Illinois & 0 & 0 & 0 & 0 \\
\hline Indiana & 0 & 0 & 0 & 0 \\
\hline lowa & 0 & 0 & 0 & 0 \\
\hline Kansas & 0 & 0 & 0.177 & 0 \\
\hline Kentucky & 0.164 & 0 & 0 & 0 \\
\hline Louisiana & 0.002 & 0 & 0 & 0 \\
\hline Maine & 0 & 0 & 0 & 0 \\
\hline Maryland & 0 & 0 & 0 & 0 \\
\hline Massachusetts & 0 & 0.223 & 0 & 0 \\
\hline Michigan & 0 & 0 & 0 & 0 \\
\hline Minnesota & 0 & 0.278 & 0 & 0 \\
\hline Missouri & 0 & 0 & 0 & 0 \\
\hline Montana & 0 & 0 & 0 & 0 \\
\hline Nebraska & 0 & 0 & 0 & 0 \\
\hline Nevada & 0.177 & 0 & 0.104 & 0.213 \\
\hline New Hampshire & 0 & 0 & 0 & 0 \\
\hline New Jersey & 0 & 0 & 0 & 0.136 \\
\hline New Mexico & 0.405 & 0 & 0.158 & 0 \\
\hline New York & 0 & 0 & 0 & 0 \\
\hline North Dakota & 0 & 0 & 0 & 0 \\
\hline Ohio & 0 & 0 & 0 & 0 \\
\hline Oklahoma & 0 & 0 & 0 & 0 \\
\hline Oregon & 0 & 0.037 & 0 & 0 \\
\hline Pennsylvania & 0 & 0 & 0 & 0 \\
\hline Rhode Island & 0 & 0 & 0.048 & 0.152 \\
\hline South Dakota & 0 & 0.015 & 0 & 0 \\
\hline Tennessee & 0 & 0 & 0 & 0 \\
\hline Texas & 0 & 0.034 & 0 & 0 \\
\hline Vermont & 0 & 0.081 & 0.013 & 0 \\
\hline Virginia & 0 & 0 & 0 & 0 \\
\hline Washington & 0 & 0.280 & 0 & 0 \\
\hline West Virginia & 0 & 0 & 0 & 0 \\
\hline Wisconsin & 0 & 0 & 0.136 & 0 \\
\hline Wyoming & 0 & 0 & 0 & 0 \\
\hline
\end{tabular}




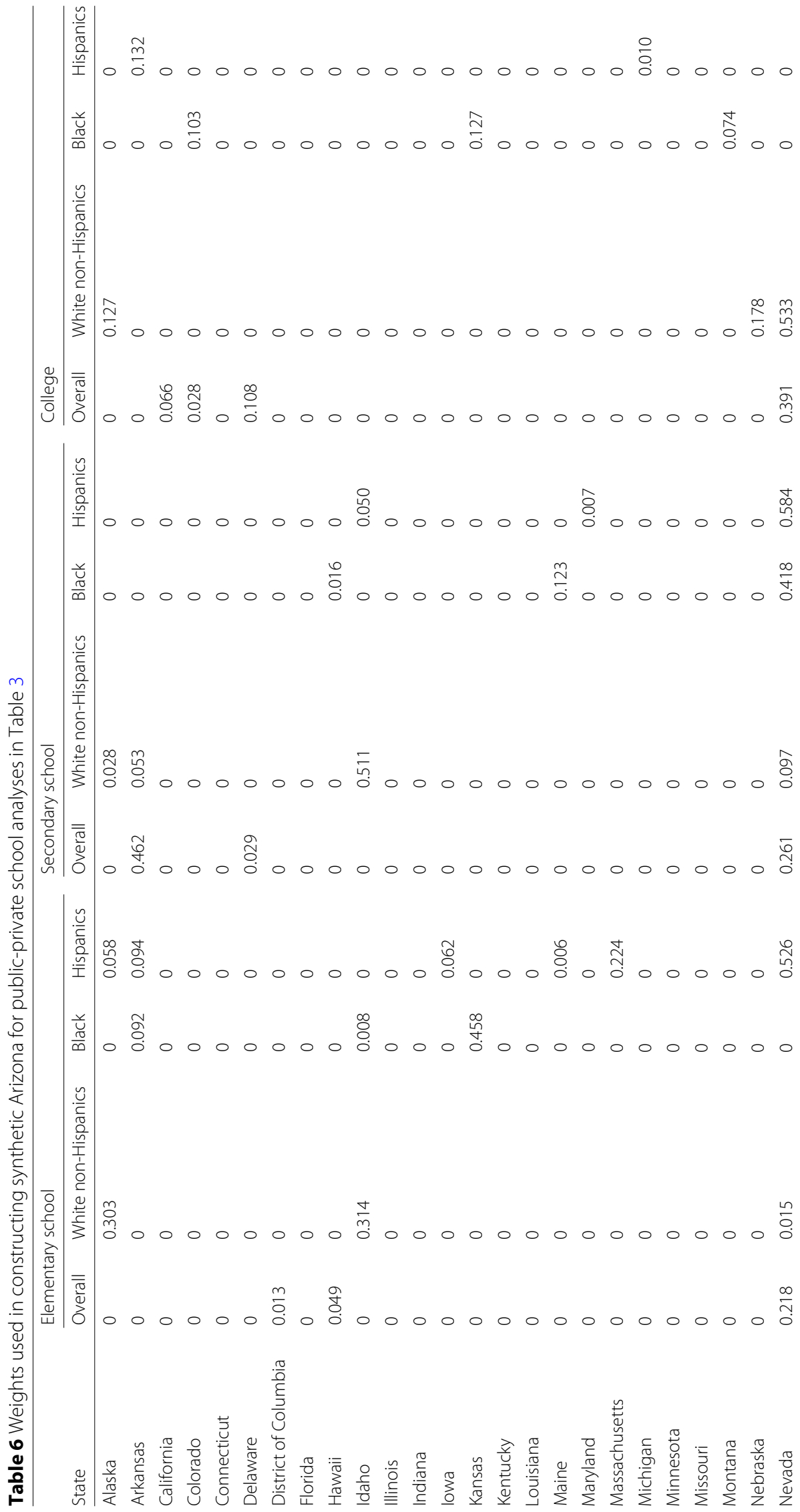




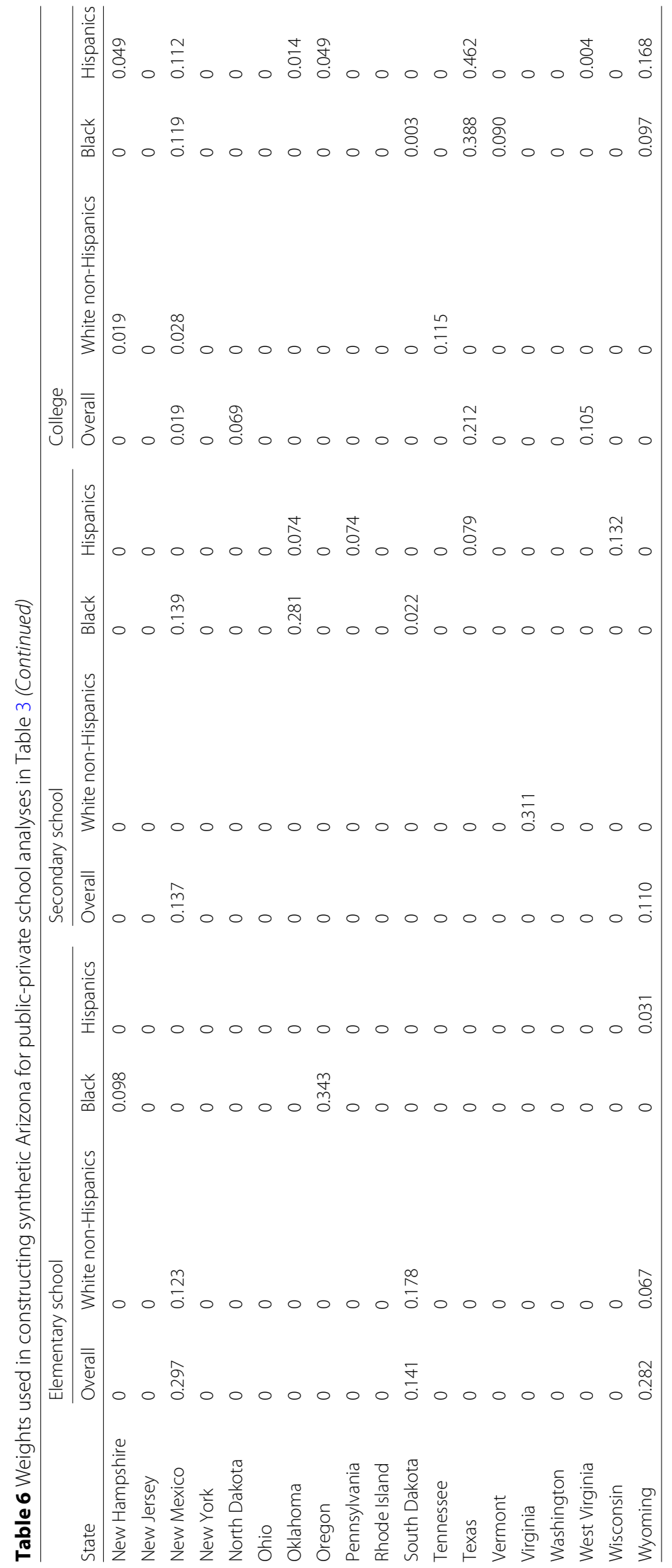




\section{Acknowledgements}

I would like to thank Joseph Cummins, Michael Bates, and Steven Helfand for their comments and suggestions. I would also like to thank the anonymous referee and the editor for the useful remarks. All mistakes are my own.

Responsible editor: Jackline Wahba

\section{Availability of data and materials}

The datasets used and/or analyzed during the current study are available from the corresponding author on reasonable request.

\section{Competing interests}

The IZA Journal of Development and Migration is committed to the IZA Guiding Principles of Research Integrity. The author declares that he has observed these principles.

\section{Publisher's Note}

Springer Nature remains neutral with regard to jurisdictional claims in published maps and institutional affiliations.

\section{Received: 19 April 2018 Accepted: 26 July 2018}

Published online: 27 December 2018

\section{References}

Abadie A, Diamond A, Hainmueller J (2010) Synthetic control methods for comparative case studies: estimating the effect of California's tobacco control program. J Am Stat Assoc 105(490):493-505

Abadie A, Diamond A, Hainmueller J (2015) Comparative politics and the synthetic control method. Am J Polit Sci 59(2):495-510

Amuedo-Dorantes C, Lopez MJ (2017) The hidden educational costs of intensified immigration enforcement. South Econ J 84(1):120-154

Amuedo-Dorantes C, Lozano F (2015) On the effectiveness of SB1070 in Arizona. Econ Inq 53(1):335-351

Betts JR, Fairlie RW (2003) Does immigration induce 'native flight' from public schools into private schools? J Public Econ 87(5-6):987-1012

Bohn S, Lofstrom M, Raphael S (2014) Did the 2007 Legal Arizona Workers Act reduce the state's unauthorized immigrant population? Rev Econ Stat 96(2):258-269

Bohn S, Lofstrom M, Raphael S (2015) Do E-verify mandates improve labor market outcomes of low-skilled native and legal immigrant workers? South Econ J 81(4):960-979

Borjas GJ (2004) Do foreign students crowd out native students from graduate programs? Tech rep. Natl Bur Econ Res:1-24. NBER Working Paper No. 10349

Cattaneo MA, Wolter SC (2015) Better migrants, better PISA results: findings from a natural experiment. 4 1:18

Chin A, Daysal NM, Imberman SA (2013) Impact of bilingual education programs on limited English proficient students and their peers: regression discontinuity evidence from Texas. J Public Econ 107:63-78

Conlon JR, Kimenyi MS (1991) Attitudes towards race and poverty in the demand for private education: the case of Mississippi. Rev Black Political Econ 20(2):5-22

Cooper B, O'Neil K (2005) Lessons from the immigration Reform and Control Act of 1986. August 2005 Migr Policy Inst Policy Brief 3:1-11

Diette TM, Uwaifo Oyelere R (2014) Gender and race heterogeneity: the impact of students with limited English on native students' performance. Am Econ Rev 104(5):412-17

Fairlie RW, Resch AM (2002) Is there "white flight" into private schools? Evidence from the National Educational Longitudinal Survey. Rev Econ Stat 84(1):21-33

Farre L, Ortega F, Tanaka R (2018) Immigration and the public-private school choice. Labour Econ 51:184-201

Gerdes C (2013) Does immigration induce "native flight" from public schools?. Ann Reg Sci 50(2):645-666

Hoxby CM (1998) Do immigrants crowd disadvantaged American natives out of higher education? Help or hindrance? The economic implications of immigration for African Americans. Econ Implications Immigration Afr Am:282

Hunt J (2017) The impact of immigration on the educational attainment of natives. J Hum Resour 52(4):1060-1118 IIE (2017) International student enrollment trends. Open Doors Rep Int Educ Exch. 1948/49-2016/17

Jackson O (2015) Does immigration crowd natives into or out of higher education?. Federal Reserve Bank of Boston Working Paper No. 15-18:1-64

Kaul A, Klößner S, Pfeifer G, Schieler M (2015) Synthetic control methods: never use all pre-intervention outcomes as economic predictors. Unpublished URI: http://www.oekonometrie.uni-saarland.de/papers/SCM_Predictors.pdf

Murray TJ (2016) Public or private? The influence of immigration on native schooling choices in the United States. Econ Educ Rev 53:268-283

Peri G, Yasenov V (2018) The labor market effects of a refugee wave: synthetic control method meets the Mariel boatlift. J Human Res:0217_8561R1

Ruggles S, Genadek K, Goeken R, Grover J, Sobek M (2015) Integrated public use microdata series: Version 6.0 [machine-readable database]. University of Minnesota, Minneapolis

Westat (2009) Findings of the e-verify program evaluation. Westat, Rockville MD 